\title{
RECESSIONS, WEALTH DESTRUCTION, AND THE TIMING OF RETIREMENT
}

\author{
Barry P. Bosworth and Gary Burtless
}

CRR WP 2010-22

Date Submitted: October 2010

Date Released: October 2010

Date Revised: October 2011

\author{
Center for Retirement Research at Boston College \\ Hovey House \\ 140 Commonwealth Avenue \\ Chestnut Hill, MA 02467 \\ Tel: 617-552-1762 Fax: 617-552-0191 \\ http://crr.bc.edu
}

Barry P. Bosworth is a senior fellow at the Brooking Institution. Gary Burtless holds the John C. and Nancy D. Whitehead Chair in Economic Studies at the Brookings Institution. The research reported here was performed pursuant to a grant from the U.S. Social Security Administration (SSA) funded as part of the Retirement Research Consortium (RRC). The opinions and conclusion expressed are solely those of the authors and do not represent the opinions or policy of SSA, any agency of the federal government, the RRC, the Brookings Institution, or Boston College. The authors are grateful to Maria Ramrath for outstanding research assistance.

(C) 2011, by Barry P. Bosworth and Gary Burtless. All rights reserved. Short sections of text, not to exceed two paragraphs, may be quoted without explicit permission provided that full credit, including $($ ) notice, is given to the source. 


\title{
About the Center for Retirement Research
}

The Center for Retirement Research at Boston College, part of a consortium that includes parallel centers at the University of Michigan and the National Bureau of Economic Research, was established in 1998 through a grant from the Social Security Administration. The Center's mission is to produce first-class research and forge a strong link between the academic community and decision makers in the public and private sectors around an issue of critical importance to the nation's future. To achieve this mission, the Center sponsors a wide variety of research projects, transmits new findings to a broad audience, trains new scholars, and broadens access to valuable data sources.

\author{
Center for Retirement Research at Boston College \\ Hovey House \\ 140 Commonwealth Avenue \\ Chestnut Hill, MA 02467 \\ phone: 617-552-1762 fax: 617-552-0191 \\ e-mail: crr@bc.edu \\ crr.bc.edu
}

Affiliated Institutions:

The Brookings Institution

Massachusetts Institute of Technology

Syracuse University

Urban Institute 


\begin{abstract}
Recessions affect the timing of retirement through two channels, a weaker job market and losses in household wealth. The two phenomena have opposite effects. A weaker economy causes employers to increase permanent job separations and reduce new hires, accelerating retirements that would otherwise have occurred later. Falling household wealth reduces the resources available to pay for retirement, discouraging older workers from leaving the workforce. We use aggregate and micro-census data on old-age labor supply as well as time series data on unemployment, stock and bond returns, and house appreciation to estimate business cycle effects on social security benefit acceptance and labor force exit. Trailing real stock and bond returns and house price appreciation have statistically significant but very small effects on old-age labor force participation. High prime-age unemployment has only a small impact on benefit acceptance and labor force participation among older women, but the effects on older men are greater. We estimate that the 4.6 percentage-point increase in prime-age unemployment between 2007 and 2009 reduced the participation rate of 60-74 year-old men by between 0.8 and 1.7 percentage points. This effect has offset the impact of declining household wealth on old-age labor force participation.
\end{abstract}




\section{Introduction}

Workers approaching the standard retirement age may be affected in the exact timing of their retirement by economic conditions. A tight labor market and rapidly rising wages can keep some workers in jobs they might have left in a weaker job market. The net effect of a recession or robust expansion on retirement is ambiguous, however. Since job finding in a recession is more difficult than it is in a growing economy, workers who lose their jobs when they are past age 62 may be induced to apply for social security benefits and shift to part-time employment or leave the workforce altogether. On the other hand, recessions can trigger steep drops in asset values. The resulting loss of wealth may encourage some older workers to postpone their retirements and remain in the workforce. In this study we examine both these channels of effect using aggregate and individual level data, and we also explore the dimensions of what is meant by retirement using data at the individual level. A worker's decision to apply for a social security pension is sometimes treated as being synonymous with retirement. Some workers may plan for gradual retirement from full-time work, however, and combine social security benefit receipt with earnings from a full- or part-time job. Thus, the decision to apply for social security benefits may be an important aspect of the retirement process, but it is an imperfect indicator of both employment status and retirement.

In this study we evaluate the retirement decision using two different analytical approaches to assessing the impact of economic conditions on retirement. The first uses aggregate statistics to measure the response of older workers to variations in labor market conditions and household wealth holdings. In particular, we examine administrative data on new retired-worker benefit awards from the Social Security Administration (SSA) and information from household surveys about the labor force status of older workers within narrow age groups. We compare these measures of labor supply with each other and with aggregate statistics on labor market conditions, such as the unemployment rate for prime-age workers, and the trailing returns on a variety of financial assets. The aggregate measures are useful for identifying trends and breaks in asset returns and retirement behavior. They provide us with helpful indicators of the link between retirement trends, on the one hand, and business cycles and asset returns, on the other. However, the statistical power of aggregate level analysis is limited, since the reliance on economy-wide averages obscures the diversity of individual responses to changing economic 
conditions. The limit on the number of observations also restricts the analysis to relatively simple models.

Our second approach relies on analysis of micro-census data from the Current Population Survey (CPS). This survey collects monthly information on the labor force status of individuals in a sample of about 60,000 households. The basic goal of the survey is to track the number of adults who are employed, unemployed, or out of the labor force. Respondents who are outside the workforce are also asked about the reason for their nonparticipation, and one possible response to this question is "retired.” The Annual Social and Economic Supplement (ASEC) to the CPS, conducted every March, obtains more detailed information about the prior year, including respondents' work status, work hours, and income sources and income amounts during that calendar year. The interview rotation pattern of the CPS provides information for the same respondent in 8 months over a 16-month period. Respondents are interviewed for 4 successive months, rotated out of the sample for 8 months, and then interviewed in 4 additional months starting one year after the first interview. The 4-8-4 rotation pattern in theory produces a 75 percent overlap in the CPS sample interviewed in successive months and a 50 percent overlap in CPS respondents who are interviewed in the same month in two successive years. After allowing for attrition, one-third to one-half of the March ASEC respondents will provide two matched interviews in successive March surveys. ${ }^{1}$

At the outset it is important to recognize the ambiguity involved in classifying workers as retired. The decision of when to apply for social security benefits can be complicated and may lead workers to apply for benefits when they are still employed. After their $62^{\text {nd }}$ birthday workers are free to apply for social security retired-worker benefits. If workers claim a pension prior to the full retirement age (currently 66), the monthly payment will be permanently reduced. If they claim benefits later they receive a credit for each year that postpone retirement beyond the full retirement age up to age 70. In 2010 the early-retirement penalty for claiming an early pension at 62 was 25 percent of the benefit entitlement at age 66. Between age 62 and the full retirement age retirees are subject to an earnings test that reduces their current benefit if their earnings exceed a certain threshold. In particular, benefits in 2009 to 2011 were reduced by 50 percent of a claimant's annual earnings above $\$ 14,160$. However, any benefits lost as a result of the application of the earnings test before the normal retirement age are effectively compensated

\footnotetext{
${ }^{1}$ Procedures for matching respondents are outlined in Feng (2008) and Madrian and Lefgren (1999)
} 
with a monthly benefit increase in later years. Since 2000 the earnings test has not applied to pensioners in years after they have attained the normal retirement age. ${ }^{2}$

In view of social security's rules on benefit claiming and earnings tests, it is unclear whether a person collecting retired-worker benefits is in fact retired. In the ASEC surveys for 2000-2009, 21 percent of workers aged 62-69 who reported receiving social security benefits in the previous year describe themselves as in the labor force in the March reference week. Among 62-69 year-olds who participate in two consecutive March surveys, 23 percent of those who report receiving social security benefits in year $\mathrm{t}-2$ also report working more than 13 weeks in year t-1. That is, almost a quarter of the 62-69 year-old respondents who collected social security benefits in one calendar year reported substantial amounts of paid employment in the following calendar year. Of course, workers may be in the labor force and employed but still consider themselves to be retired. On the other hand, many people who collect retired-worker benefits may not think of themselves as retired. Finally, it is worth noting that some people past 62 who are eligible for retired-worker benefits may not claim a pension even though they consider themselves retired. For many retired workers, especially married men, it makes sense to delay benefit claiming, even after retirement, in order to maximize expected lifetime benefits to the retired worker and his or her spouse (Webb and Sun 2009).

If a worker's retirement status is difficult to determine solely with social security administrative data, it is also hard to ascertain using information in the CPS. In the monthly household survey, older people who report themselves as being out of the workforce may be retired or they may be temporarily absent from the labor force as a result of poor health or discouraging job prospects. Only about two-thirds of older workers who report a change in status from employed in the previous calendar year to out of the workforce in March classify themselves as "retired" when they are asked the reason for their nonparticipation. In some previous studies, respondents who are out of the workforce in March after being in the labor force for more than 13 weeks in the previous year are classified as "retired" (Coile and Levine 2009). In the matched ASEC, however, about 30 percent of these retirees will reenter the workforce by the following March.

\footnotetext{
${ }^{2}$ While the reduction for early retirement is actuarially fair and ensures no added cost of early retirees to the system, it does raise the risk that early claimants will exhaust their other assets and fall below the poverty line in later years. The effects of the earnings test on the labor supply of older workers was recently examined in Engelhardt and Kumar (2006) and Loughran and Haider (2005).
} 
In section 2 below we examine SSA data on new benefit awards for retired workers. The information on new retired-worker awards offers the most direct and straightforward evidence on the influence of changes in economic conditions on individuals' decision to replace or supplement market earnings with a government-provided pension. In section 3, we compare the SSA administrative records on new awards with the survey data on social security benefits provided by the CPS. This allows us to assess the quality of the survey information. In addition, the CPS data permit us to extend the analysis to look more directly at the implications of changing economic conditions on late-career labor supply. In section 4, we use aggregate time series analysis to measure the response of old-age labor supply to changes in labor market conditions and returns on assets that are likely to be part of the savings portfolios of workers nearing retirement. In addition, we use micro-census data from 30 years of monthly CPS files to estimate the effects of weak job markets and fluctuating asset prices on the labor force status of 55-69 year-old workers. The last section of the paper contains a brief summary of conclusions.

\section{New benefit awards}

Figure 1 shows trends in new retired-worker benefit awards for years between 1970 and 2010. The number of new awards shows a strong upward trend, with a particularly large jump in 2008 and 2009 when the economy entered a deep recession and the leading edge of the baby boom generation attained age 62. There are two important breaks in the data. The first occurred in 1985 and was due to changes in administrative reporting procedures. Before 1985 the age classification of new awards was based on a claimant's age at the end of the calendar year of the award, whereas in later years it was based on the age in the actual month of the award. In addition, after 1984 the age distribution data were based on a one-percent sample of social security records. The post-1984 raw data on awards show a sharp rise in the number of awards at age 62 with a partial downward offset in awards at age 63. Another temporary jump in the rate of new awards occurred in 2000 and was due to the elimination of the earnings test for working beneficiaries once they attained the age of full benefit entitlement.

The awards data are strongly influenced by the growth in the number of insured workers who are eligible for retired-worker benefits. The proportion of male workers who are socialsecurity insured by age 62 has exceeded 95 percent for several decades, but the fraction of women who are insured is still rising, climbing from about 65 percent in 1980 to an estimated 85 percent in 2010. In addition, the oldest members of the baby boom generation attained the early 
retirement age in 2008, producing a surge in the number of workers eligible for Old-Age Insurance (OAI) or retired-worker benefits. For both these reasons, the growth in the insured population has been substantial (see Figure 2). In the following analysis we scale the new awards data by the number of people of the same age in the insured population. In some analyses, the office of the Social Security Actuary has reported the data as a retirement rate (Motsiopoulos and Tucker, 2005). To perform this calculation analysts exclude from the denominator the number of insured persons who are already in benefit status (retired or disabled). However, we do not have access to these administrative data over a long enough time span to analyze new awards over a number of past business cycles. We therefore focus on benefit claiming rates in populations that include some insured workers who are already receiving benefits.

The ratio of new awards to the relevant insured population within major age categories is displayed in Figure 3. The shift toward earlier retirement is evident in the growth after 1970 in the new benefit award rate for individuals age 62-64, shown in the top panel. Note also that there was an offsetting decline in the new award rate for retired workers aged 65-69. The trend toward early benefit claiming stopped in the mid-1980s and reversed beginning in the late 1990s. The number of new benefit awards to those over age 64 flattened after the mid 1980s and then rose after 2002. Meanwhile, the proportion of the insured population age 62-64 applying for a retirement benefit declined from 22 to 17 percent between 2000 and 2007.

Recent trends are at least partly due to the gradual increase in the full benefit claiming age, which increased from 65 to 66 starting in 2000. Workers reaching age 62 in 2000 were the first ones affected by the rise in the age of entitlement for full benefits. As the full benefit claiming age rises, the financial penalty for early benefit claiming also increases, producing a smaller benefit for workers claiming pensions at the earliest pension claiming age. The lower panel of Figure 3 highlights the very high claiming rate for workers when they first become eligible for OAI benefits at age 62. Early benefit claiming peaked in the early 1990s at 50 percent of the insured population, and it reached a low of 38 percent in 2007 before jumping in the 2008-2009 recession. The trend away from early benefit claiming not only reflects the larger financial penalty for early claiming but also the gradual trend toward higher employment and labor force participation rates among the population past age 60 (see below). The data do, however, show a jump in new awards for 62-year-olds in the 2008-2009 recession. In 2010, which was one of weak economic recovery, the benefit claiming rate at age 62 fell below the 
previous low attained in 2007, implying that the slow trend toward later benefit claiming was only temporarily interrupted by the severe recession. The increase in benefit claiming among workers aged 63-64 was much more modest than that among 62-year-olds in the 2008-2009 recession.

When we examine data on new awards back to the early 1970s, we see some sensitivity of the new award rate to recessions, though the sensitivity appears to be modest over much of the period. The unemployment rate of Americans between 25 and 54 doubled between 1973 and 1975, rising from 3.2 percent to 6.4 percent, and it increased from 4.2 percent to 8.0 percent between 1979 and 1983. There were more modest increases in the prime-age unemployment rate in 1991-1992 and 2001-2003. However, in Figure 3 we see little change in the proportion of the insured population claiming benefits in those recessions. The jump in new benefit awards in the 2008-2009 recession is clearly visible in the data, however, especially at age 62.

More formally, we have estimated a set of simple regressions that relate the administrative estimates of new award rates to the current and lagged unemployment rate of 2554 year-olds. The unemployment rate of prime-age workers provides the most straightforward indicator of the health of the labor market because it is comparatively unaffected by major swings in the age profile of the American workforce. We included a quadratic time trend in the regression to capture the changed secular trends in claiming behavior, a shift term to account for the definitional changes after 1984, and a categorical variable to adjust for the elimination of the earnings test in 2000 for workers past the full retirement age. Separate estimates were obtained for male and female insured workers and for both sexes combined.

The regression estimates are reported in Table 1. A striking aspect of the results is the contrast in benefit claiming behavior of men and women. There is a significant effect of increased prime-age unemployment on the claiming behavior of men, but the effect is weaker and less precisely estimated for women. Consider first the effects on the benefit claiming behavior of all insured workers between ages 62 and 69, shown in the first column of Table 1. The impact of a higher unemployment rate on new awards for 62-69 year-old men is positive and statistically significant, though the initial effect of a jump in unemployment is almost entirely reversed in the second year. In contrast, a higher prime-age unemployment rate has a proportionally smaller and less precisely estimated impact on new retired-worker awards to women. Like the estimated impact on men, the impact on women of an unemployment rate 
change that persists for two years is almost exactly reversed in the second year. For both sexes combined the estimated impact of higher unemployment on benefit claiming is positive and highly statistically significant. In the results for both sexes combined, a jump in the unemployment rate that persists two years is not fully reversed in the second year. This finding implies that an elevated unemployment rate will have a continuing effect on benefit claiming, although the effect of a one-time jump will be smaller in the second and later years than it is in the first.

The most revealing findings are displayed in the second column of Table 1, which shows estimates of the impact of the unemployment rate on benefit claiming among 62-year-olds. Since age 62 is the youngest age at which insured workers can claim a retired-worker benefit, it is not possible that a jump in benefit claiming in an earlier calendar year can reduce the proportion of insured population still eligible to claim a new award in the current year. Benefit claiming rates at age 63 and later ages can obviously be affected by the percentage of insured workers who earlier filed claims for new awards. The results for 62-year-olds show large and statistically significant effects of the unemployment rate on benefit claiming among men but not among women. An increase in the unemployment rate that persists more than a year initially boosts women's benefit claiming rate at age 62, but the effect largely disappears after a year. Among men the effect on benefit claiming is larger in the initial year, and almost two-thirds of the initial effect persists in later years. The estimated effect on men of a one-percentage-point rise in the unemployment rate is economically as well as statistically significant. In 2006 and 2007 about 37 percent of social-security-insured 62-year-old men claimed new retired-worker benefits. The cumulative rise in the prime-age unemployment rate between 2007 and 2010 was 4.9 percentage points. If all of the increase had occurred in one year, the initial impact of the increase is predicted to boost the number of new awards by slightly more than one-tenth, to slightly more than 41 percent of insured 62-year-old men. If the jump in unemployment persisted for more than a year, the effect in the second year would have been about a third smaller, and slightly less than 40 percent of 62-year-olds would have claimed retired-worker benefits in that year. The results for both sexes combined, shown in the bottom panel of Table 1, are between those for men and women. The initial effect of a 4.9-percentage-point increase in the unemployment rate is to increase benefit claiming among 62-year-olds by about 9 percent (or 3.4 percent of the social-security-insured 62-year-old population). If the 4.9-point jump in unemployment persists 
for a second year, the impact on new awards falls in half (to 1.7 percent of the insured 62-yearold population).

We note that the coefficient estimates are quite sensitive to the inclusion of the 20082009 recession in the analysis. If data for 2008-2010 are excluded from the analysis, the estimated effect of the unemployment rate on benefit claiming shrinks dramatically and is much less precisely estimated. In the case of male 62-year-olds, for example, the predicted impact of a 1-percentage-point jump in the unemployment rate shrinks by half when data for 2008-2010 are excluded from the regression. The estimated effects of unemployment on women and on both sexes combined fall even more dramatically. Thus, the estimates shown in Table 1 depend crucially on the distinctive and large increase in new retired-worker awards in the 2008-2009 recession (see Figure 3). Compared with responses in earlier recessions, the jump in new benefit awards in 2008-2009 was unusually large, especially among men.

The two right-hand columns in Table 1 show estimated responses among 62-64 year-olds and 65-69 year-olds. For the older age group there is little evidence that retired-worker awards are responsive to the prime-age unemployment rate. The response coefficients are small and very imprecisely estimated, both for men and women. Responses are larger and more economically and statistically significant for workers who are below the normal retirement age. A 4.9-percentage-point increase in the unemployment rate would initially boost the new award rate of 62-64 year-old men by 2.7 percentage points, or a bit less than one-sixth of the average award rate in 2006-2007, before the onset of the most recent recession. The surge in new awards would shrink by half in the following year, even if the unemployment rate remained high. The proportional response of new awards to 62-64 year-old insured women is about half the size of that among men, and a larger fraction of the estimated response is reversed in the second year after a rise in unemployment.

We interpret these results to show a noticeable response of retired-worker awards to the business cycle. Workers who are eligible for retired-worker benefits and who have not yet claimed them are more likely to apply for benefits in a downturn than they are in an economy near full employment. The response to unemployment rate changes is proportionally larger and more precisely estimated for men than for women, and it is concentrated among insured workers who are younger than the normal retirement age, especially men who have just attained the earliest benefit claiming age. Both among men and women the impact of a higher 
unemployment rate is larger when unemployment first rises than it is when higher unemployment persists for a year or longer. Readers should treat these results with some caution, since they are unusually affected by experience in the most recent recession. The response of new retired-worker awards in recessions before 2008 was far more muted than it was in 2008-2009.

\section{Survey and administrative measures of retirement ages}

Compared with the administrative data published by the SSA, household surveys such as the CPS provide a much wider range of information about the context in which individuals make their retirement and labor supply decisions. It is not obvious, however, that the administrative and survey data capture the same phenomena. In this section we report on some tests aimed at showing the consistency of the various measures of retirement decisions in the CPS with the retirement trends shown in the administrative records.

In the monthly CPS individuals answer questions about their labor supply in terms of employed, unemployed, or not in the labor force. For people who report that they are out of the labor force, interviewers also ask about the reasons for nonparticipation. One listed response is that the person is "retired." Thus, in theory it is possible to distinguish between a retiree and a discouraged worker who has temporarily withdrawn from the workforce. Unfortunately, the monthly labor force survey contains no information about whether respondents are currently receiving a social security pension. In the March (ASEC) survey, interviewers ask detailed questions about respondents' work histories and income in the previous year. In particular, respondents are asked about retirement benefits, including social security. Given the 4-8-4 rotation pattern for the CPS, we would expect respondents to the March survey to be interviewed in two consecutive ASEC surveys, and it is possible to match their responses for the two years. Thus, for a matched subset of respondents to the March survey, it is possible to compare incomes in year $\mathrm{t}-1$ and $\mathrm{t}-2$ to identify respondents who appear to be new beneficiaries in $\mathrm{t}-1$. (Year $\mathrm{t}$ is the calendar year in which the second ASEC survey takes place.)

We constructed three measures of change in labor market status that that might be expected to correspond to various concepts of a new retirement. The first identifies as "newly retired” persons in the March survey who report being in the labor force more than 13 weeks during the previous calendar year but report that in the March reference week they are out of the labor force. The second stricter definition of the "newly retired" identifies a subset of those 
classified as retirees under the first measure, namely, those who indicate they are retired when they are asked the reason for their nonparticipation in the March reference week. Our third measure of newly retired workers uses the matched ASEC data to identify individuals who report no social security benefits in year t-2 but who report receiving social security payments in year t1. This concept comes closest to the definition of a new award in the SSA administrative data.

Estimates of the alternative measures of retirement are displayed in Figure 4. Panel A shows the average age profile of new retirees under the first two definitions of new retirees described above. The top line in the panel shows the age profile of retirees under the first definition; the lower line shows the age profile under the second, more restrictive definition, which classifies workers as new retirees only if they say the reason for nonparticipation is that they are "retired." The age profiles are estimated by combining the March (ASEC) CPS samples for 2001-2009. Note that the age profile of new retirees under both definitions is broadly similar to that for social security awards. There are peaks in the retirement rate at ages 62 and 65. Understandably the peaks are not as pronounced at age 62 as in the administrative data, which show that nearly half of the social-security-insured population applies for a benefit award at that age.

A comparison of the retiree age profiles displayed in Panel A shows there is a substantial difference at younger ages between the proportion of the population that exits the workforce and the proportion that reports being retired. The gap between the two age profiles narrows considerably at older ages. This suggests that a rising percentage of older people who exit the work force probably consider their exit to be permanent. There are substantial discouraged worker effects at all ages, but the proportion of exiting workers who might be classified as "discouraged" declines at ages after $62 .^{3}$

Panel B shows the age profile of workers who are new retirees under our third definition, which classifies workers as newly retired in year t- 1 if they received social security benefits in that year but did not receive any social security in the previous calendar year (year t-2). As expected, we see a sharp increase in the percentage of the population that receives a new benefit award around age 62. Note that the ASEC data would reflect both new retiree awards and new benefits received by spouses of retired workers. The estimates of the age pattern are less precise

\footnotetext{
${ }^{3}$ The number of workers exiting from the work force was a stable 2-3 percent of the population between ages 30 and 50, but the proportion of these workers who report they are retired is essentially zero.
} 
than in the administrative data, but the percentage of people with new benefit awards is approximately 20 percent for people between 61 and 65. This percentage drops off sharply at ages past 65.

The time series pattern of retirement under alternative definitions is displayed in Panels C and D of Figure 4. In each case the retirement rate is expressed as a percentage of the population in the indicated age groups. Both the proportion of the aged population that is reported as exiting the workforce and the proportion that gives retirement as the reason for exit show a pattern of secular decline after 1980 (see Panel C). There was, however, a pronounced upward shift in the percentage of exits that were reported as "retirements" between the 1980s and 1990s. ${ }^{4}$

Panel D shows the time series trend in new retirements under a definition that links retirement to social security benefit acceptance. The two alternative estimates of the time series trend reflect two different sources of information about the number of new social security recipients between ages 61 and 68 (where the respondent's age is measured in the first survey year). The top line in the panel is based on estimates from matched ASEC household samples, as described above. The lower line is based on SSA's administrative reports of the number of new retired-worker awards. The measure based on the matched ASEC samples seems broadly similar to the measure produced by administrative data. The number of new beneficiaries shown in the ASEC is higher than the number shown in administrative reports, but the difference reflects new disabled-worker beneficiaries (who are excluded from the SSA estimates) and an unknown number of dependent spouses, who are excluded from SSA's estimates but are included in the estimates derived from the household survey. ${ }^{5}$ Both sets of estimates show a sharp increase in new benefit awards when the earnings test was changed in 2000. In this respect we interpret the evidence in Panel D to show a reasonably high degree of correspondence between the administrative records and the survey reports. Neither measure of the retirement rate shows much cyclical sensitivity.

\footnotetext{
${ }^{4}$ The questionnaire was redesigned in 1993 in a way that altered the relative percentages of men and women reporting retirement, and the combined effect was to show a small reduction in fraction of people exiting the workforce who classified themselves as retired. The increase in the reported retirement rate in the late 1980s seems unrelated to any change in the survey.

${ }^{5}$ The matched ASEC data also show greater year-to-year volatility in the new beneficiary rate. In recent years, the size of the matched ASEC sample is only about 25 percent of the full March sample in each year. Only half of the sample is eligible for a match with the prior year, and attrition between the two survey dates is substantial.
} 
Taken as a whole, the evidence displayed in Figure 4 shows considerable divergence in retirement patterns depending on the concept of retirement that is used. Retirement rates appear higher, especially in late middle age, if retirement is solely based on a respondent's current labor force status. If we do not classify workers as "retired" until they describe themselves as retired (rather than simply out of the workforce), retirement rates appear considerably lower at those ages. Social security benefit acceptance is an even more ambiguous indicator of retirement. Although the age pattern of benefit acceptance broadly mirrors the age profile of labor force withdrawal, the correspondence is far from exact. Nonetheless, the survey measure of new beneficiaries seems generally consistent with the administrative data. Under a variety of concepts of retirement, however, we see little visual evidence in Figure 4 that the rate of retirement is strongly influenced by the business cycle.

\section{Impact of unemployment and investment returns on labor supply at older ages}

Trends in old-age labor supply have been the subject of considerable empirical research (Quinn and Burkhauser 1990; Burtless and Quinn 2001; Burtless 2008; Gustman and Steinmeier 2009). During most of the twentieth century labor force participation rates at ages past 60 declined. This long term trend ceased and then reversed direction in the 1990s. Participation rates at older ages have been rising in recent years among both men and women. Analysis of labor force trends before the mid-1970s is based on data in decennial census records and special surveys targeted on the aged, because detailed monthly tabulations of the labor force status of older Americans were not published by the Bureau of Labor Statistics until 1976.

The Bureau reports the monthly labor force status of adult Americans in 5-year age groups up through age 74. In addition, it publishes additional tabulations for broader age groups and for 60-61 year-olds and 62-64 year-olds. Separate statistics on the latter two groups are published because of the obvious importance of social security's early entitlement age (62) for workers' retirement behavior. Researchers with access to the public-use CPS files can analyze work patterns in even narrower age groups, though the limited size of the monthly CPS samples reduces the precision of monthly statistics for very small age groups.

Trends in participation rates at older ages are displayed in Figures 5 and 6. Participation rates among women past age 60 began to rise after the mid-1980s, and they have increased considerably since that time (Figure 5). Among 65-69 year-old women, participation rates have approximately doubled since 1985, and they have increased about 16 percentage points among 
women between 60 and 64. The increase in participation rates among 55-59 year-old women was even larger than among older women. Moreover, the rise of participation in this age group began a little earlier than it did among women past 60. In addition to the monthly estimates of female labor force participation, Figure 5 also displays the smoothed trend in participation where the trend line is estimated as a third order polynomial function of time It is hard to see much evidence in the chart that deviations from the trend lines are systematic or especially large during recessionary periods.

The trends in older males’ participation rates are displayed in Figure 6. The historical data show a strong pattern of participation decline during the late 1970s and early 1980s, continuing a fall in participation at these ages that began several decades earlier. There was a rebound in older men's participation starting sometime in the 1990s. The rebound is particularly noticeable in the two older age groups. The participation rate of 65-69 year-olds has increased about 12 percentage points since 1990, and the participation rate of 60-64 year-old men rose about 8 percentage points after the mid-1990s. Among men between 55 and 59 there has been a slight increase in participation rates in the past decade.

In the remainder of this section we analyze the aggregate determinants of labor force status at older ages using monthly statistics on labor force participation rates and the employment-population ratio for the period 1976-2010. We are interested in two main factors that affect the attractiveness of labor force exit. The first is the state of labor market. It seems plausible to expect that low-unemployment job markets will tend to keep older workers in the labor force and entice labor force dropouts back into the active workforce. We measure the state of the job market using the unemployment rate of 25-54 year-old adults (seasonally adjusted). One advantage of this variable is that it only reflects the labor force choices of nonaged adults, that is, people who are too young to be included in any of the age groups we analyze. Besides the prime-age unemployment rate, our specification includes indicators of the returns savers obtain on three kinds of assets - stocks, long duration U.S. government bonds, and owneroccupied homes. In the 2007 Survey of Consumer Finances, slightly more than half the net worth of families headed by a person between 55 and 74 years old was held in stocks, bonds, and a primary residence. (About 19\% of net worth was held as stocks, $4 \%$ as bonds, and 28\% as equity in a principal residence.) We measure the return on stocks using the total real annual rate of return on stocks in the Standard and Poors 500 index. The total return reflects the returns 
provided by reinvested dividends plus stock price changes. The nominal return is deflated using the CPI-U-RS to derive the real return on stock investment. Bond returns are calculated based on the returns of a 10-year constant maturity portfolio of U.S. government bonds. The return consists of reinvested interest payments and price appreciation or depreciation on the bonds in the portfolio. The total nominal return is converted to real returns using the CPI-U-RS.

To calculate the rate of real appreciation of owner-occupied homes we use the Federal Housing Finance Agency’s house price index. According to the FHFA's documentation, the index “... measures average price changes in repeat sales or refinancings on the same properties. This information is obtained by reviewing repeat mortgage transactions on single-family properties whose mortgages have been purchased or securitized by Fannie Mae or Freddie Mac.” [http://www.fhfa.gov/Default.aspx?Page=81] Thus, the index attempts to measure the price increase or decline of typical homes, holding constant the quality of the homes. This index begins in 1975. For house appreciation in years before 1975 we relied on a discontinued BLS price series known as the Home Purchase Index, which was once a component of the CPI. Like the FHFA index, the Home Purchase Index attempted to measure house appreciation holding fixed the quality of dwellings. To calculate the real rate of house appreciation, we deflated the nominal house price index numbers using the CPI-U-RS. (The modern version of the CPI-U does not use the House Purchase Index. Shelter costs are now measured in the CPI-U using the concept of rental equivalence.) To be sure, the price appreciation of a house offers an imperfect approximation of the real return that homeowners derive from ownership. Most Americans who own a home also have a mortgage. If house prices are rising, leveraged owners will derive bigger returns on their home investment than implied by the percentage rise in the house prices. If house prices are falling, they will experience larger proportional wealth losses than implied by the price decline. However, older homeowners have smaller mortgages than average, so the rate of price appreciation may offer a better approximation of their returns.

Asset returns are important to workers nearing retirement if they have accumulated a significant amount of savings to finance their retirement. A sharp rise in asset prices near the end of a worker's career can substantially increase the worker's retirement wealth, permitting an earlier retirement or a higher flow of consumption in old age. Workers with little retirement savings should be less affected by changes in asset returns. To examine the influence of asset returns on labor force behavior we tried a variety of definitions of an asset's trailing returns. The 
definition that produced the largest variance in returns focused on trailing returns over the previous twelve months. It is unclear, however, whether most retirement savers monitor their savings often enough to react to a rise or fall in returns that lasts only one year. We also experimented with 3-year and 5-year trailing returns. These definitions show less variability than one-year returns, but the 1976-2010 period still saw wide swings in the real returns on the three asset classes we examined.

The regression results reported below show our estimates of a basic aggregate-level model of labor force participation and the employment-population ratio. In all our specifications we include second- or third-order polynomial time trends to reflect determinants of labor market behavior that were left out of our model. The time trends are always highly significant, as should be evident from casual inspection of Figures 5 and 6. (The coefficients on the trend variables are not reported in Tables 2 and 3 below.) In addition, the basic specification includes the prime-age unemployment rate in the current month and in three past months $(3,6$, and 12 months before the current period). This specification allows a flexible response to changes in the unemployment rate. In the results reported below we show coefficient estimates for three asset classes. The most parsimonious specification includes only the trailing stock market return. More elaborate specifications show the effects of adding bond returns and house-price appreciation to the model. Preliminary inspection of the results showed significant autocorrelation in the error terms. To address this problem we estimated a first-order auto-regressive model. The coefficient estimates for women are displayed in Table 2, while results for men are shown in Table 3. Columns 1, 2, and 3 in the Tables show coefficients for models that predict the monthly labor force participation rate. The results in columns 4, 5, and 6 show coefficient estimates for models that predict the employment-population ratio. We report results for three age groups - 55-59 year-olds (at the top of the table), 60-64 year-olds (in the middle), and 65-69 year-olds (on the bottom).

The estimates for women show very little evidence that the prime-age unemployment rate affects the labor force participation decisions of older women (see the results displayed in Table 2 under columns 1, 2, and 3). The F statistic for including the four unemployment variables in the model is displayed immediately below the sum of the estimated coefficients on the four unemployment rate variables. In spite of the flexibility in our specification of the potential response of participation rates to the contemporaneous and lagged values of unemployment, the 
unemployment terms are never jointly significant. Moreover, the sum of the coefficients on the current and lagged unemployment terms is always close to zero. The prime-age unemployment rate is a significant determinant of the employment-population ratio of women who are between 55 and 59 (see the results reported in columns 4, 5, and 6 of Table 2). However, this finding simply confirms that employment and unemployment rates in this group of women are responsive to common shocks in the labor market that also affect the unemployment rate of prime-age workers. The actual labor supply of 55-59 year-old women is responsive to the strength and weakness of the overall labor market, but their decision to participate in the labor force shows little detectable influence of labor market tightness. For women in the two older age groups the unemployment rate variables seldom have a significant impact on the employmentpopulation ratio, although in this case the effects clearly have the anticipated sign. In the case of women in the oldest age group shown, 65-69, the point estimates imply a 1-percentage-point increase in the prime-age unemployment rate would reduce the employment-population ratio by between 0.07 and 0.25 percentage points, or about 0.4 to 1.4 percent of the average participation rate in this age group. The effect is not small, but it is imprecisely determined by the data.

The effect of the prime-age unemployment rate on the labor force participation decisions of older men is larger and more significant than it is in the case of older women (see the results in columns 1, 2, and 3 of Table 3), although this is mainly true for men past the age of 60 . The participation rate of men who are between 55 and 59 shows little responsiveness to the unemployment rate. For the two older age groups, however, the effects are larger and more precisely determined. Among 60-64 year-old men the participation rate drops between 0.18 and 0.33 percentage points in response to a 1-point rise in the jobless rate. Among 65-69 year-old men, the estimated drop ranges between 0.18 and 0.49 percentage points depending on the other variables included in the model. In the recent recession the prime-age unemployment rate increased 4.6 percentage points, rising from an average of 3.7 percent in 2007 to 8.3 percent in 2009. The results in Table 3 imply that this increase could have reduced the labor force participation rate by 0.8 to 1.5 percentage points among 60-64 year-old men and by 0.8 to 2.3 percentage points among 65-69 year-old men. In estimates not shown we find that the responsiveness is similar for men slightly younger and slightly older than the social security early entitlement age. That is, the labor force participation rates of men 60-61 move about the same in response to a jump in the unemployment rate as the participation rates of 62-64 year- 
olds.

Table 3 also shows, not surprisingly, that the actual employment rates of older men are significantly affected by changes in the prime-age unemployment rate. These effects are generally larger than the effects on labor force participation. We find for example that the change in the labor force participation rate is only about 10 to 20 percent of the change in the employment-population ratio among men between 55 and 59. This percentage rises in older age groups. Among 60-64 year-old men the change in the labor force participation rate is between 30 percent and 40 percent of the estimated change in the employment-population rate. Among 65-69 year-olds the comparable percentage is 80 percent to 100 percent. In other words virtually the entire estimated response in the group's employment rate is also eventually reflected as a drop in its labor force participation rate. A weak job market depresses the employment rate of this age group, and nearly all of the employment-rate reduction is reflected as a drop in the group's participation rate.

The other results in Tables 2 and 3 show our estimates of the impact of trailing asset returns on the labor force participation rates and employment-population ratios of older Americans. We show the results based on trailing asset returns over the previous 36 months. Our estimates when we use trailing returns over a 60-month period are qualitatively and quantitatively similar. However, the results when using 12-trailing returns differed noticeably from those using a longer return horizon. To keep the discussion simple, we focus solely on results based on the 3-year horizon. The estimates for women suggest that both labor force participation and the employment-population ratio are modestly but statistically significantly sensitive to trailing stock market returns. A higher stock return in the most recent 3 years tends to reduce older women's participation and employment. The effect of higher government bond returns on participation and employment probably has the same sign, but it is imprecisely estimated in our data. The effects of stock returns on behavior are proportionately more important for women in the two older age groups. Thus, the impacts of both stock and bond returns on women's labor force status are in the expected direction, but the effect is not large in comparison with the variation in women's work behavior over this period. For example, a onestandard-deviation (10.1-percentage-point) increase in the trailing real return on stocks would only reduce 55-59 year-olds' participation rate by 0.4 percentage points, or about 1.1 percent of the average participation rate in the estimation period. The proportional effects (though not the 
absolute effects) on the participation and employment rates are larger for women in the older age groups. This may either mean that women are more sensitive to wealth changes as they grow older or that stock and bond holdings are larger and more important among women who remain in the workforce after age 60 or 65 . Increases in bond returns have an impact on labor force status that is broadly similar to that produced by an increase in stock returns, but the effect sizes are proportionately smaller and sometimes insignificant. This may be due to the fact that bond investments represent a smaller fraction of older women's retirement savings portfolios.

The estimated effects of house price appreciation on women's participation and employment are marginally significant and sometimes puzzling in sign. Among women under 60 the effect of recent house appreciation is to reduce modestly the participation rate and employment-population ratio. A one-standard-deviation (2.7-percentage-point) increase in the rate of house appreciation would induce a 0.2 percentage point decline in the participation rate and a somewhat smaller drop in the employment-population ratio. For women who are over age 60 increasing home values are estimated to have the opposite effect on participation and employment. Instead of withdrawing from the work force when house prices rise, the coefficient estimates suggest women boost their participation and employment rates. The estimated effect on behavior is, however, very small in comparison with the variation in participation and employment rates over the period covered by the data. In sum, most of the evidence of the influence of recent asset returns on labor market behavior shows effects that are usually in the expected direction but quantitatively small.

The estimates for men show a somewhat different pattern of effects (Table 3). None of the results for 55-59 year-old men show noticeable effects of real asset returns on participation rates or retirement. The only marginally significant effect is the estimated impact of house prices on labor force participation, and this effect is slight. A one-standard deviation increase in real house price increases would reduce the labor force participation rate of 55-59 year-old men by less than 0.2 percentage points. The estimated effects of increased stock and bond returns on older men are usually in the expected direction, but similar to the results for women they suggest quantitatively small responses to increases or reductions in the trailing real return. For example, a 1-standard-deviation increase in the real return on stocks is predicted to reduce the labor force participation rate of 60-64 year-old and 65-69 year-old men by 0.2 to 0.3 percentage points. This represents about 0.3 percent of the average participation rate of 60-64 year-old men and 0.7 to 
1.0 percent of the participation rate of men between 65 and 69 . Thus, the estimated effects have the anticipated sign, but they are small in relation the typical variability of the participation rate.

As in the case of women, the estimated response of older men to appreciation in house prices presents a puzzle. Instead of encouraging older workers to leave the work force and employment at an earlier age, which would be expected, a jump in real house prices is associated with a rise in both participation and employment rates. In the case of 60-64 year-old men, a onestandard-deviation (2.7-percentage-point) increase in average house appreciation is predicted to increase the participation rate by 0.23 percentage points (about 0.4 percent of the average participation rate in the estimation period). The impact on the employment-population rate of this group is even bigger. The unexpected effect is larger still in men between 65 and 69. The one-standard-deviation increase in home price appreciation causes the participation rate in this age group to rise by 0.38 percentage points and the employment rate to increase 0.56 percentage points. In view of the fact that the typical participation and employment rates in this group average less than 30 percent, the size of these predicted effects is notable. One possible explanation for the puzzling sign of the effect is that rising home prices not only make some older workers wealthier they also make it more expensive for retirees to move and for aged renters to pay for shelter. Still, the overwhelming impression from the time series estimates is that the trailing real returns on stock and bond investments and the rate of real house appreciation have quite modest impacts on both the labor force participation and employment rates of aging men and women.

A similar result is obtained if we estimate the determinants of labor force participation using micro-census data. To do this we assembled interview responses on labor force status and basic demographic variables from the monthly Current Population Survey files covering the period from April 1978 through March 2010. We then used the linear probability model to predict labor force participation within 5-year age groups, separately for women and men between ages 55 and 74 . The prediction model included indicator variables reflecting each respondent's state of residence, race, educational attainment, marital status, and exact year of age. In addition, the specification included a common cubic time trend, indicator variables for each month to capture seasonal effects, the nationwide prime-age unemployment rate, and the difference between the unemployment rate in the respondent's state and the nationwide 
unemployment rate in the same month. ${ }^{6}$ As in our time series analysis we included variables to reflect the 3-year trailing annual real rates of return on stocks and bonds and the 3-year trailing rate of real house price appreciation. Stock and bond returns are identical for workers throughout the country, but the rate of house price appreciation varies across localities. The FHFA provides quarterly estimates of state-level house price changes, and we used these statelevel data to impute trailing house price appreciation estimates for each respondent in the CPS sample.

Partial results of our labor force participation regressions are displayed in Table 4. The dependent variable for each regression is the respondent's labor force participation $(1=$ participant and $0=$ nonparticipant). The only coefficients we display are those on the unemployment rate and trailing real return variables. Four sets of results are shown for each gender, corresponding to our estimates for the four 5-year age groups. In parenthesis below the estimated coefficients we show p-values. These are calculated based on cluster-robust standard errors, which take into account the clustering (by state) in the data (Moulton 1990; Nichols and Shaffer 2007).

The coefficient estimates for older women uniformly show a quantitatively small and statistically insignificant impact of the unemployment rate on labor force participation. In contrast, higher national and state unemployment rates tend to reduce labor force participation among older men, and the effect is progressively larger at more advanced ages. A onepercentage point increase in the prime-age national unemployment rate is estimated to reduce the participation rate of 60-74 year-old men by between 0.3 and 0.4 percentage points. By implication, the 4.6 percentage-point jump in the unemployment rate in 2008 and 2009 may have reduced the participation rate in these age groups by 1.3 to 1.7 percentage points. This estimated effect is close to the one reported in Table 3, where aggregate time series data are used to estimate the relationship between male participation rates and the national unemployment rate. Especially in the oldest age group this would represent a sizeable proportional decline in participation. Our specification of the effect of unemployment distinguishes between the separate effects of the national-level rate and the difference between the state- and national-level

\footnotetext{
${ }^{6}$ The BLS does not publish estimates of the prime-age unemployment rate at the state level. In measuring the difference between state- and national-level unemployment rates we therefore used estimates of the unemployment rate for the population 16 and older.
} 
rates. Note that among men who are older than 65, a jump in the local unemployment rate when the national unemployment rate remains unchanged has an even bigger adverse effect on participation than the same rise in unemployment if it occurs uniformly across all states. This result suggests that labor force participation among the oldest men may be particularly sensitive to the local unemployment rate. The estimated effects of trailing real stock and bond returns and home price appreciation on older women's participation rates usually have the expected sign, but the impacts are typically quite small in comparison with the variability in women's labor force participation over the estimation period. A partial exception is the response of 60-64 year-old women to trailing stock returns and 65-69 year-old women to both stock and bond returns. A one-standard-deviation increase in the trailing bond return, for example, is estimated to reduce the participation rate of 65-69 year-old women by 0.4 percentage point. Although this is a small absolute effect, it is about 2 percent of the average labor force participation rate of women in the age group. A one-standard-deviation increase in the trailing stock return would reduce the participation rate of women in this age group by a similar absolute and proportional amount. Thus, there is some evidence in Table 4 that women near the normal retirement age are modestly sensitive to stock and bond returns. The results for older men show smaller and less consistent effects of trailing returns on participation rates. The effects of house price changes on the male participation rate have the expected sign, but the effects are small and are not statistically significant. Note that, unlike our earlier estimates, the estimated effects of house price change in Table 4 are based on observed price changes in each respondent's state rather than in the nation as a whole. This may account for the discrepancy between the estimated effects of house price changes in Tables 2 and 3, on the one hand, and those in Table 4. All of the estimated effects of house price change in Table 4 have the anticipated sign, but none suggest that house price movements have a noticeable effect on older Americans’ participation rate.

\section{Summary}

In sum, the findings in the previous section suggest that, with few exceptions, the effects of trailing real returns on participation and employment rates are typically quite modest, even when the effects are statistically significant and precisely estimated. Some of the most consistent results show small effects of trailing stock and bond returns on women's and older men's participation and employment rates. As most economists would anticipate, higher real returns on 
assets, which tend to boost the value of retirement savings, typically push down the labor force participation and employment rates of older men and women. The size of this effect, however, is quantitatively very modest. Our findings based on time series analysis of aggregate data uncovered a puzzling response of participation and employment rates to higher home prices. This puzzle was apparent both among women and among men older than 60. Unexpectedly, the findings from the aggregate time series regressions suggest that increasing home prices tend to boost participation and employment rates among the elderly. This anomalous result disappears when we estimate the determinants of labor force participation in the monthly CPS files. In that analysis we use state-level rather than national-level house prices to measure the real rate of home appreciation. Whichever analysis method is used, however, the estimated size of response to house price changes is small compared with the variation in participation and employment rates we see during the period covered by our data. Most of the effects of asset returns on labor supply behavior conform with the expectations of economists and ordinary citizens. The size of these effects, however, is quantitatively small.

We find essentially no evidence that fluctuations in the prime-age unemployment rate have an important or systematic effect on the labor force participation rates of women past age 55. There is clear evidence of an impact of higher unemployment rates on the employmentpopulation ratio of 55-59 year-old women, but this effect does not translate into a noticeable impact on the level of labor force participation among these women. In contrast, the prime-age unemployment rate has a significant, though not a particularly large, effect on the participation rate of older men. For men between 55 and 59, there is little evidence that weak job markets drive large numbers of men from the work force. There is, of course, good evidence that weak job markets reduce the employment rates of older men. Just as men in younger age groups lose their jobs and suffer high unemployment when the job market is weak, so, too, do men in older age groups. At ages past 60 and especially past 65, however, the reduced employment levels caused by a weak job market very quickly translate into reduced labor force participation rates.

The findings from our analysis of labor force participation and employment rates conform broadly with the findings in previous parts of the paper. Our analysis of new social security claims uncovered little cyclical responsiveness of women's claims to the business cycle but a noticeable impact of the business cycle on men's benefit claims. This analysis could certainly be improved with better administrative data on the size of the social-security-insured 
population that has not yet claimed a social security benefit. Nonetheless, our results imply that higher unemployment rates tend to boost new awards for retired-worker benefits, especially among men who have recently reached 62, the earliest benefit claiming age. Our conclusion, then, is that a weak job market and plummeting asset returns almost certainly have effects in the expected direction. The effects, however, are oftentimes small in relation to variations we have seen in labor force participation, retirement rates, and pension claiming behavior over the past three decades. 


\section{References}

Burtless, Gary. 2008. “The Rising Age of Retirement in Industrial Countries.” Working Paper 2008-6 (Chestnut Hill, MA: Retirement Research Center at Boston College).

Burtless, Gary, and Joseph F. Quinn. 2001. "Retirement Trends and Policies to Encourage Work among Older Americans,” in P.P. Budetti, R.V. Burkhauser, J.M. Gregory, and H.A. Hunt, eds., Ensuring Health and Income Security for an Aging Workforce (Kalamazoo, MI: Upjohn).

Chan, Sewin and Ann Huff Stevens. 2004. "How Does Job Loss Affect the Timing of Retirement?” Contributions to Economic Analysis \& Policy, Vol. 3, No. 1, article 5.

Coile, Courtney and Phillip Levine. 2009. “The Market Crash and Mass Layoffs: How the Current Economic Crisis May Affect Retirement,” NBER Working Paper 15395.

Engelhardt, Gary, and Anil Kumar. 2006. "The Repeal of the Retirement Earnings Test and the Labor Supply of Older Men" (Working Paper 2007-1, Center for Retirement Research, Boston College, Chestnut Hill, MA, December), available at http://crr.bc.edu/working_papers/the_repeal_of_the_retirement_earnings_test_and_the_labor_sup ply_of_olde.html (accessed July 14, 2008).

Feng, Shuaizhang. 2008. "Longitudinal Matching f Recent Current Population Surveys: Methods, Non-Matches and Mismatches,” Journal of Economic and Social Measurement 33: 241-52.

Gustman, Alan L., and Thomas L. Steinmeier. 2009. "How Changes in Social Security Affect Recent Retirement Trends.” Research on Aging, 31(2):261.

Gustman, Alan, Thomas Steinmeier, and Nahid Tabatabai. 2010. "What the Stock Market Decline Means for the Financial Security and Retirement Choices of the Near-Retirement Population,” Journal of Economic Perspectives, Vol 24, No. 1 (Winter): 161-182.

Hurd, Michael D., Monika Reti, Susann Rohwedder. 2009. "The Effect of Large Capital Gains or Losses on Retirement", in David Wise (ed.), Developments in the Economics of Aging. Chicago: University of Chicago Press.

Loughran, David, and Steven Haider.2005. "Do the Elderly Respond to Taxes on Earnings? Evidence from the Social Security Retirement Earnings Test." RAND Corporation working paper 223, Santa Monica, CA, January 2005), available at: www.rand.org/pubs/working_papers/WR223/index.html.

Madrian, Brigitte, and Lars John Lefgren. 1999. “A Note on Longitudinally Matching Current Population Survey (CPS) Respondents.” National Bureau of Economic Research, technical working paper t0247 (November)..

Motsiopoulos, Chris, and Richard B. Tucker. 2005. Short-Range Actuarial Projections of the Old-Age, Survivors, and Disability Insurance Program, 2005, actuarial study no.119, Office of the Chief Actuary, Social Security Administration.

Moulton, Brent R. 1990. “An Illustration of a Pitfall in Estimating the Effects of Aggregate Variables in Micro Units,” Review of Economics and Statistics, Vol. 72, No. 2 (May): 334-338. 
Nichols, Austin, and Mark E. Schaffer. 2007. “Clustered Standard Errors in Stata,” United Kingdom Stata Users’ Group Meetings 2007, No. 07, Stata Users Group.

Quinn, Joseph F. and Richard V. Burkhauser. 1990. "Work and Retirement”, in: R.H. Binstock and L.K. George (eds.), Handbook of Aging and the Social Sciences, San Diego: Academic Press.

Sass, Stephen, Courtney Monk, and Kelly Haverstick. 2010. “Workers’ Response to the Market Crash: Save More, Work More? Research Brief, Center for Retirement Research at Boston College Number 10-3 (February).

Webb, Anthony, and Wei Sun. 2009. "How Much Do Households Really Lose By Claiming Social Security at Age 62?” Working Paper 2009-11 (Chestnut Hill, MA: Center for Retirement Research at Boston College). 
Table 1. Regression Results: The Impact of the Unemployment Rate on Social Security Retired Worker Awards, by Gender, 1971-2010

\begin{tabular}{|c|c|c|c|c|c|c|}
\hline & Ages 62-69 & Age 62 & Age 63 & Age 64 & Age 62-64 & Ages $65-69$ \\
\hline & \multicolumn{6}{|c|}{ Men } \\
\hline Unemployment in year $\mathrm{t}$ & $\begin{array}{l}0.169 * * \\
(0.014)\end{array}$ & $\begin{array}{c}0.862^{* * *} \\
(0.000)\end{array}$ & $\begin{array}{c}0.369 * * * \\
(0.000)\end{array}$ & $\begin{array}{c}0.252 \\
(0.218)\end{array}$ & $\begin{array}{c}0.560 * * * \\
(0.000)\end{array}$ & $\begin{array}{c}0.124 \\
(0.169)\end{array}$ \\
\hline Unemployment in year t-1 & $\begin{array}{c}-0.163^{* *} \\
(0.031)\end{array}$ & $\begin{array}{l}-0.301 \\
(0.178)\end{array}$ & $\begin{array}{c}0.013 \\
(0.879)\end{array}$ & $\begin{array}{c}- \\
0.474 * * \\
(0.040)\end{array}$ & $\begin{array}{c}-0.264 * * \\
(0.040)\end{array}$ & $\begin{array}{l}-0.164 \\
(0.101)\end{array}$ \\
\hline $\begin{array}{l}\text { Joint F-Statistic } \\
\text { Significance of F-Statistic }\end{array}$ & $\begin{array}{l}4.41^{* *} \\
(0.019) \\
\end{array}$ & $\begin{array}{c}15.17^{* * * *} \\
(0.000) \\
\end{array}$ & $\begin{array}{c}30.89 * * * \\
(0.000) \\
\end{array}$ & $\begin{array}{c}3.00^{*} \\
(0.062) \\
\end{array}$ & $\begin{array}{c}17.65^{* * *} \\
(0.000) \\
\end{array}$ & $\begin{array}{c}1.88 \\
(0.166) \\
\end{array}$ \\
\hline & \multicolumn{6}{|c|}{ Women } \\
\hline Unemployment in year $\mathrm{t}$ & $\begin{array}{c}0.071 \\
(0.289)\end{array}$ & $\begin{array}{c}0.436 \\
(0.136)\end{array}$ & $\begin{array}{c}0.082 \\
(0.397)\end{array}$ & $\begin{array}{l}-0.070 \\
(0.653)\end{array}$ & $\begin{array}{c}0.296 * * \\
(0.043)\end{array}$ & $\begin{array}{l}-0.022 \\
(0.743)\end{array}$ \\
\hline Unemployment in year t-1 & $\begin{array}{l}-0.086 \\
(0.246)\end{array}$ & $\begin{array}{l}-0.407 \\
(0.206)\end{array}$ & $\begin{array}{c}0.104 \\
(0.333)\end{array}$ & $\begin{array}{l}-0.291^{*} \\
(0.095)\end{array}$ & $\begin{array}{l}-0.235 \\
(0.140)\end{array}$ & $\begin{array}{l}-0.072 \\
(0.332)\end{array}$ \\
\hline $\begin{array}{l}\text { Joint F-Statistic } \\
\text { Significance of F-Statistic }\end{array}$ & $\begin{array}{c}3.19 * \\
(0.053)\end{array}$ & $\begin{array}{c}1.45 \\
(0.248)\end{array}$ & $\begin{array}{l}3.77^{* *} \\
(0.032)\end{array}$ & $\begin{array}{l}5.60 * * * \\
(0.008)\end{array}$ & $\begin{array}{c}2.64^{*} \\
(0.085) \\
\end{array}$ & $\begin{array}{c}2.11 \\
(0.135)\end{array}$ \\
\hline
\end{tabular}

Both Sexes

\begin{tabular}{lcccccc}
\hline Unemployment in year t & $\begin{array}{c}0.208^{* * *} \\
(0.003)\end{array}$ & $\begin{array}{c}0.695^{* * *} \\
(0.002)\end{array}$ & $\begin{array}{c}0.240^{* * *} \\
(0.003)\end{array}$ & $\begin{array}{c}0.059 \\
(0.553)\end{array}$ & $\begin{array}{c}0.411^{* * *} \\
(0.001)\end{array}$ & $\begin{array}{c}0.059 \\
(0.452)\end{array}$ \\
& & & & & & \\
Unemployment in year t-1 & $-0.135^{*}$ & -0.342 & 0.053 & $-0.385^{*}$ & $-0.233^{* * *}$ & -0.132 \\
& $(0.065)$ & $(0.139)$ & $(0.524)$ & $(0.057)$ & $(0.001)$ & $(0.133)$ \\
& & & & & & \\
Joint F-Statistic & $6.83^{* * *}$ & $8.00^{* * *}$ & $17.61^{* * *}$ & $3.37^{* *}$ & $8.69^{* * *}$ & 1.74 \\
Significance of F-Statistic & $(0.003)$ & $(0.001)$ & $(0.000)$ & $(0.045)$ & $(0.001)$ & $(0.190)$ \\
\hline & & & & & & 40 \\
Number of Observations & 40 & 40 & 40 & 40 & 40 & 40 \\
\hline
\end{tabular}

Notes: P-values are reported in parentheses. The dependent variable is new retired-worker awards as a percent of the insured population from 1971-2010. Aside from the prime-age unemployment rate the regression specification also includes a quadratic time trend, a categorical variable for the elimination of the earnings test in 2000, and a shift term for 1984 and earlier years to account for a change in how the new awards were recorded in Social Security Administration statistics. 


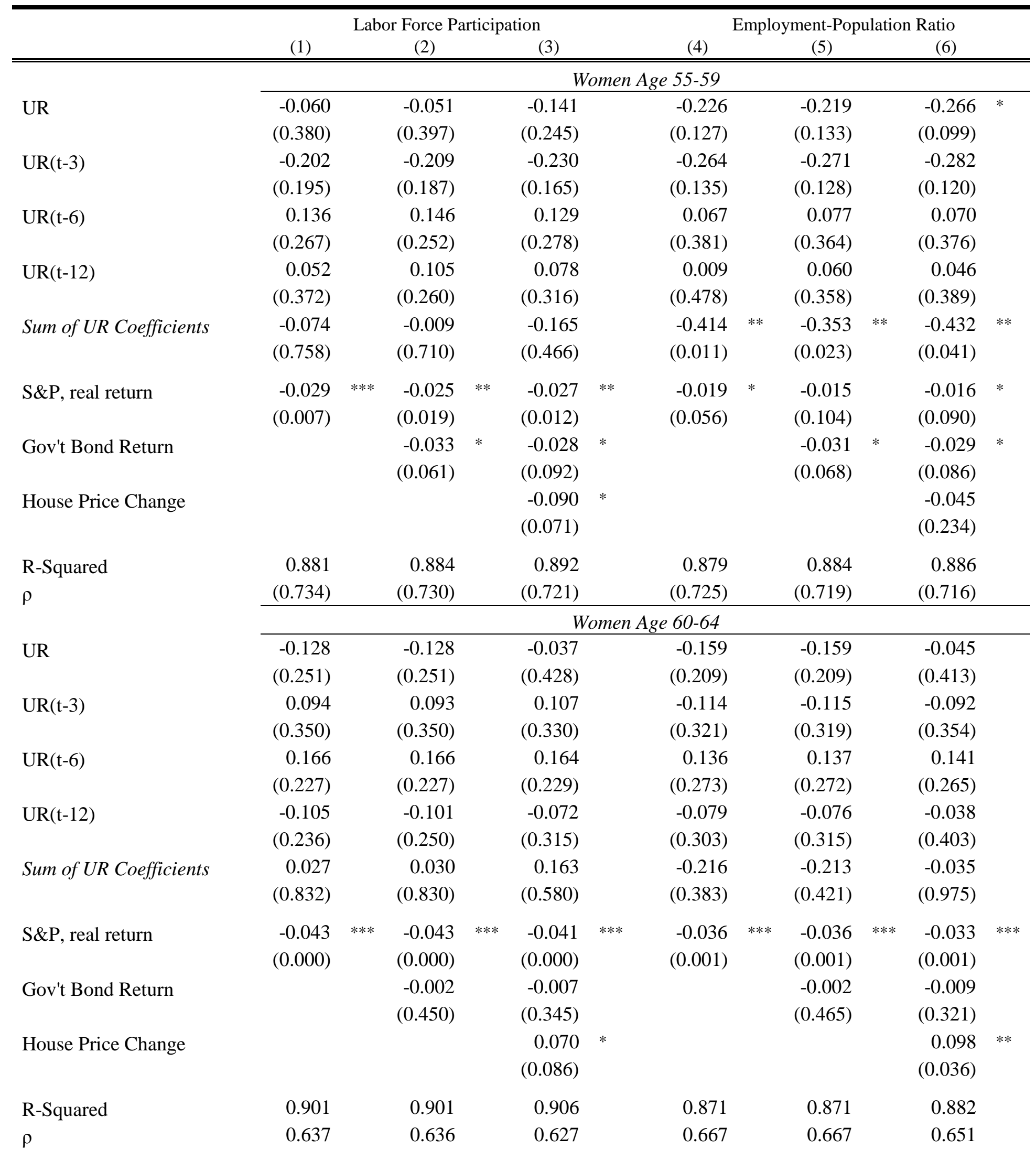




\section{Table 2. Regression Estimates for 55-69 Year-Old Women (continued)}

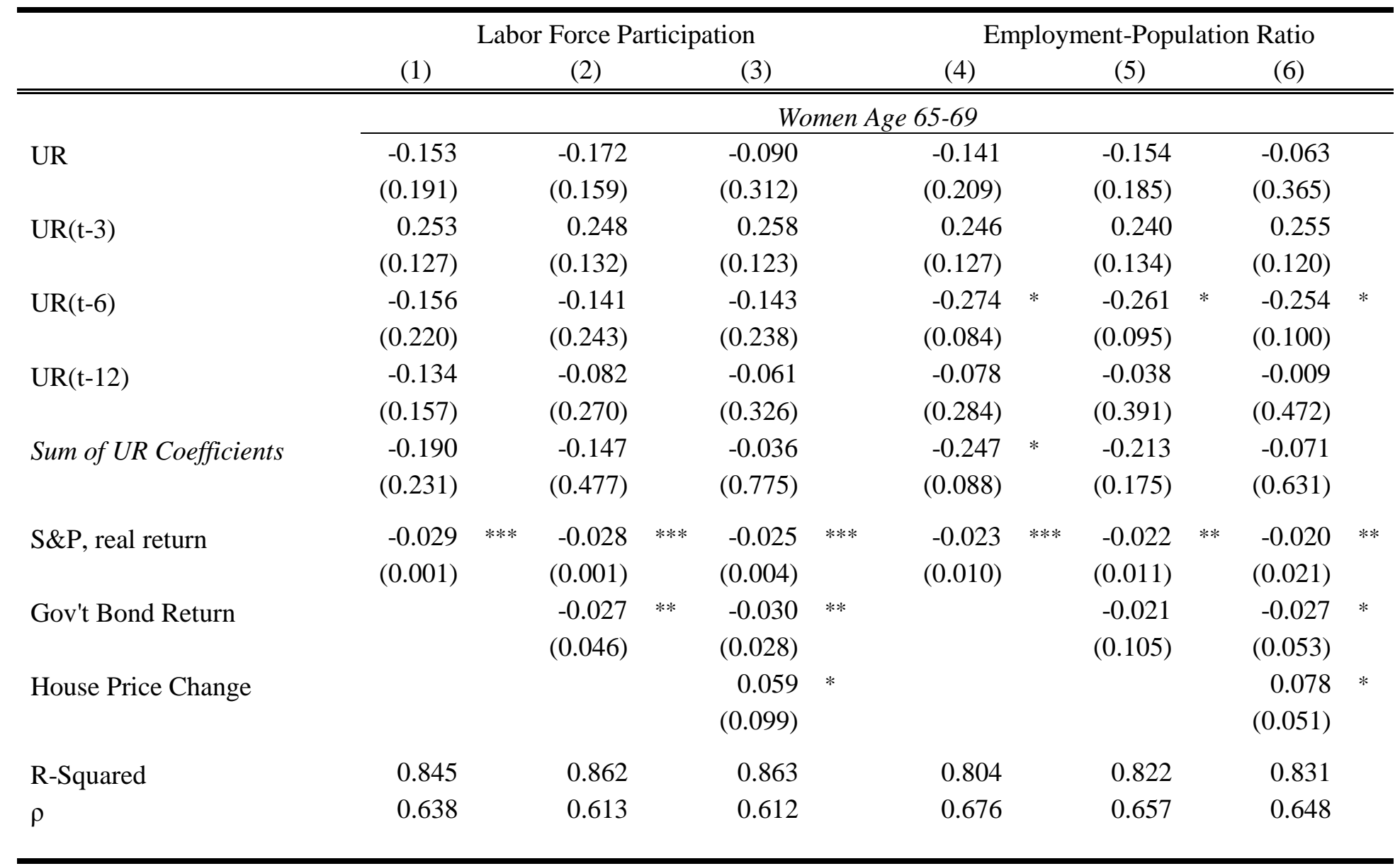

Notes: Monthly data cover the period from June 1976 through June 2010. P-values are in parenthesis. 


\begin{tabular}{|c|c|c|c|c|c|c|c|c|c|c|c|c|}
\hline & \multicolumn{6}{|c|}{ Labor Force Participation } & \multicolumn{6}{|c|}{ Employment-Population Ratio } \\
\hline & (1) & & (2) & & (3) & & (4) & & (5) & & (6) & \\
\hline & \multicolumn{12}{|c|}{ Men Age 55-59 } \\
\hline UR & $\begin{array}{r}0.043 \\
(0.386)\end{array}$ & & $\begin{array}{r}0.048 \\
(0.376)\end{array}$ & & $\begin{array}{r}-0.020 \\
(0.450)\end{array}$ & & $\begin{array}{r}-0.376 \\
(0.013)\end{array}$ & $* *$ & $\begin{array}{r}-0.369 \\
(0.015)\end{array}$ & $* *$ & $\begin{array}{r}-0.393 \\
(0.015)\end{array}$ & $* *$ \\
\hline $\mathrm{UR}(\mathrm{t}-3)$ & $\begin{array}{r}-0.103 \\
(0.289)\end{array}$ & & $\begin{array}{r}-0.106 \\
(0.283)\end{array}$ & & $\begin{array}{r}-0.123 \\
(0.253)\end{array}$ & & $\begin{array}{r}-0.286 \\
(0.092)\end{array}$ & * & $\begin{array}{r}-0.292 \\
(0.087)\end{array}$ & * & $\begin{array}{r}-0.297 \\
(0.085)\end{array}$ & * \\
\hline $\mathrm{UR}(\mathrm{t}-6)$ & $\begin{array}{r}0.096 \\
(0.289)\end{array}$ & & $\begin{array}{r}0.100 \\
(0.282)\end{array}$ & & $\begin{array}{r}0.087 \\
(0.309)\end{array}$ & & $\begin{array}{r}0.058 \\
(0.385)\end{array}$ & & $\begin{array}{r}0.067 \\
(0.368)\end{array}$ & & $\begin{array}{r}0.065 \\
(0.372)\end{array}$ & \\
\hline $\mathrm{UR}(\mathrm{t}-12)$ & $\begin{array}{r}-0.110 \\
(0.193)\end{array}$ & & $\begin{array}{r}-0.093 \\
(0.237)\end{array}$ & & $\begin{array}{r}-0.118 \\
(0.182)\end{array}$ & & $\begin{array}{r}-0.175 \\
(0.104)\end{array}$ & & $\begin{array}{r}-0.136 \\
(0.169)\end{array}$ & & $\begin{array}{r}-0.144 \\
(0.157)\end{array}$ & \\
\hline Sum of UR Coefficients & $\begin{array}{r}-0.074 \\
(0.822)\end{array}$ & & $\begin{array}{r}-0.052 \\
(0.904)\end{array}$ & & $\begin{array}{r}-0.174 \\
(0.654)\end{array}$ & & $\begin{array}{r}-0.779 \\
(0.000)\end{array}$ & $* * *$ & $\begin{array}{r}-0.730 \\
(0.000)\end{array}$ & $* * *$ & $\begin{array}{r}-0.769 \\
(0.000)\end{array}$ & $* * *$ \\
\hline S\&P, real return & $\begin{array}{r}-0.006 \\
(0.257)\end{array}$ & & $\begin{array}{r}-0.005 \\
(0.313)\end{array}$ & & $\begin{array}{r}-0.006 \\
(0.265)\end{array}$ & & $\begin{array}{r}0.006 \\
(0.274)\end{array}$ & & $\begin{array}{r}0.009 \\
(0.187)\end{array}$ & & $\begin{array}{r}0.008 \\
(0.208)\end{array}$ & \\
\hline Gov't Bond Return & & & $\begin{array}{r}-0.011 \\
(0.258)\end{array}$ & & $\begin{array}{r}-0.008 \\
(0.326)\end{array}$ & & & & $\begin{array}{r}-0.023 \\
(0.103)\end{array}$ & & $\begin{array}{r}-0.021 \\
(0.120)\end{array}$ & \\
\hline House Price Change & & & & & $\begin{array}{r}-0.068 \\
(0.086)\end{array}$ & $*$ & & & & & $\begin{array}{r}-0.021 \\
(0.345)\end{array}$ & \\
\hline R-Squared & 0.400 & & 0.401 & & 0.417 & & 0.474 & & 0.484 & & 0.487 & \\
\hline \multirow[t]{2}{*}{$\rho$} & 0.744 & & 0.743 & & 0.736 & & 0.699 & & 0.695 & & 0.693 & \\
\hline & \multicolumn{12}{|c|}{ Men Age 60-64 } \\
\hline UR & $\begin{array}{r}0.292 \\
(0.068)\end{array}$ & * & $\begin{array}{r}0.290 \\
(0.069)\end{array}$ & * & $\begin{array}{r}0.385 \\
(0.032)\end{array}$ & $* *$ & $\begin{array}{r}0.120 \\
(0.278)\end{array}$ & & $\begin{array}{r}0.124 \\
(0.273)\end{array}$ & & $\begin{array}{r}0.263 \\
(0.113)\end{array}$ & \\
\hline $\mathrm{UR}(\mathrm{t}-3)$ & $\begin{array}{r}-0.503 \\
(0.021)\end{array}$ & $* *$ & $\begin{array}{r}-0.501 \\
(0.022)\end{array}$ & $* *$ & $\begin{array}{r}-0.480 \\
(0.026)\end{array}$ & $* *$ & $\begin{array}{r}-0.705 \\
(0.004)\end{array}$ & $* * *$ & $\begin{array}{r}-0.708 \\
(0.004)\end{array}$ & $* * *$ & $\begin{array}{r}-0.678 \\
(0.005)\end{array}$ & $* * *$ \\
\hline $\mathrm{UR}(\mathrm{t}-6)$ & $\begin{array}{r}0.110 \\
(0.315)\end{array}$ & & $\begin{array}{r}0.109 \\
(0.318)\end{array}$ & & $\begin{array}{r}0.120 \\
(0.301)\end{array}$ & & $\begin{array}{r}0.063 \\
(0.398)\end{array}$ & & $\begin{array}{r}0.065 \\
(0.396)\end{array}$ & & $\begin{array}{r}0.072 \\
(0.384)\end{array}$ & \\
\hline $\mathrm{UR}(\mathrm{t}-12)$ & $\begin{array}{r}-0.219 \\
(0.088)\end{array}$ & * & $\begin{array}{r}-0.228 \\
(0.085)\end{array}$ & * & $\begin{array}{r}-0.202 \\
(0.113)\end{array}$ & & $\begin{array}{r}-0.283 \\
(0.042)\end{array}$ & $* *$ & $\begin{array}{r}-0.268 \\
(0.057)\end{array}$ & * & $\begin{array}{c}-0.237 \\
(0.080)\end{array}$ & $*$ \\
\hline Sum of UR Coefficients & $\begin{array}{r}-0.320 \\
(0.004)\end{array}$ & $* * *$ & $\begin{array}{r}-0.330 \\
(0.007)\end{array}$ & $* * *$ & $\begin{array}{r}-0.177 \\
(0.069)\end{array}$ & * & $\begin{array}{r}-0.805 \\
(0.000)\end{array}$ & $* * *$ & $\begin{array}{r}-0.788 \\
(0.000)\end{array}$ & $* * *$ & $\begin{array}{r}-0.580 \\
(0.000)\end{array}$ & $* * *$ \\
\hline S\&P, real return & $\begin{array}{r}-0.018 \\
(0.061)\end{array}$ & * & $\begin{array}{r}-0.019 \\
(0.060)\end{array}$ & * & $\begin{array}{r}-0.016 \\
(0.089)\end{array}$ & * & $\begin{array}{r}-0.011 \\
(0.180)\end{array}$ & & $\begin{array}{r}-0.010 \\
(0.210)\end{array}$ & & $\begin{array}{r}-0.006 \\
(0.316)\end{array}$ & \\
\hline Gov't Bond Return & & & $\begin{array}{r}0.004 \\
(0.418)\end{array}$ & & $\begin{array}{r}0.000 \\
(0.497)\end{array}$ & & & & $\begin{array}{c}-0.007 \\
(0.361)\end{array}$ & & $\begin{array}{r}-0.014 \\
(0.258)\end{array}$ & \\
\hline House Price Change & & & & & $\begin{array}{r}0.083 \\
(0.090)\end{array}$ & * & & & & & $\begin{array}{r}0.112 \\
(0.031)\end{array}$ & $* *$ \\
\hline R-Squared & 0.559 & & 0.561 & & 0.564 & & 0.582 & & 0.579 & & 0.593 & \\
\hline$\rho$ & 0.707 & & 0.706 & & 0.705 & & 0.668 & & 0.67 & & 0.663 & \\
\hline
\end{tabular}




\section{Table 3. Regression Estimates for 55-69 Year-Old Men (continued)}

\begin{tabular}{|c|c|c|c|c|c|c|c|c|c|c|c|c|}
\hline & \multicolumn{6}{|c|}{ Labor Force Participation } & \multicolumn{6}{|c|}{ Employment-Population Ratio } \\
\hline & \multicolumn{2}{|l|}{$(1)$} & \multicolumn{2}{|l|}{$(2)$} & \multicolumn{2}{|l|}{$(3)$} & \multicolumn{2}{|l|}{ (4) } & \multicolumn{2}{|l|}{ (5) } & \multicolumn{2}{|l|}{$(6)$} \\
\hline & & & & & & Men A & $65-69$ & & & & & \\
\hline \multirow[t]{2}{*}{ UR } & -0.190 & & -0.193 & & -0.012 & & -0.225 & & -0.229 & & 0.029 & \\
\hline & $(0.19)$ & & $(0.19)$ & & $(0.48)$ & & $(0.16)$ & & $(0.15)$ & & $(0.45)$ & \\
\hline \multirow[t]{2}{*}{$\mathrm{UR}(\mathrm{t}-3)$} & 0.104 & & 0.103 & & 0.132 & & -0.057 & & -0.061 & & -0.019 & \\
\hline & $(0.36)$ & & $(0.36)$ & & $(0.32)$ & & $(0.42)$ & & $(0.42)$ & & $(0.47)$ & \\
\hline \multirow[t]{2}{*}{$\mathrm{UR}(\mathrm{t}-6)$} & -0.183 & & -0.171 & & -0.157 & & -0.122 & & -0.103 & & -0.065 & \\
\hline & $(0.24)$ & & $(0.26)$ & & $(0.27)$ & & $(0.32)$ & & $(0.35)$ & & $(0.40)$ & \\
\hline \multirow[t]{2}{*}{$\mathrm{UR}(\mathrm{t}-12)$} & -0.222 & * & -0.185 & & -0.145 & & -0.200 & & -0.153 & & -0.101 & \\
\hline & $(0.10)$ & & $(0.14)$ & & $(0.20)$ & & $(0.13)$ & & $(0.20)$ & & $(0.28)$ & \\
\hline \multirow{2}{*}{ Sum of UR Coefficients } & -0.491 & $* * *$ & -0.446 & $* * *$ & -0.182 & & -0.604 & $* * *$ & -0.546 & $* * *$ & -0.157 & \\
\hline & $(0.00)$ & & $(0.00)$ & & $(0.53)$ & & $(0.00)$ & & $(0.00)$ & & $(0.76)$ & \\
\hline \multirow[t]{2}{*}{ S\&P, real return } & -0.028 & $* * *$ & -0.026 & $* *$ & -0.021 & $* *$ & -0.020 & * & -0.018 & $*$ & -0.012 & \\
\hline & $(0.01)$ & & $(0.01)$ & & $(0.04)$ & & $(0.05)$ & & $(0.08)$ & & $(0.16)$ & \\
\hline \multirow[t]{2}{*}{ Gov't Bond Return } & & & -0.021 & & -0.032 & $*$ & & & -0.029 & $*$ & -0.046 & $* *$ \\
\hline & & & $(0.15)$ & & $(0.05)$ & & & & $(0.09)$ & & $(0.01)$ & \\
\hline \multirow[t]{2}{*}{ House Price Change } & & & & & 0.140 & $* * *$ & & & & & 0.207 & $* * *$ \\
\hline & & & & & $(0.01)$ & & & & & & $(0.00)$ & \\
\hline R-Squared & 0.720 & & 0.730 & & 0.755 & & 0.646 & & 0.663 & & 0.726 & \\
\hline$\rho$ & 0.623 & & 0.615 & & 0.593 & & 0.649 & & 0.637 & & 0.587 & \\
\hline
\end{tabular}

Notes: Monthly data cover the period from June 1976 through June 2010. P-values are in parenthesis. 
Table 4. Micro-Census Regression Estimates of Labor Force Participation among 55-74 Year-Olds

\begin{tabular}{|c|c|c|c|c|c|c|c|c|}
\hline \multirow{4}{*}{ Prime-age unemployment rate } & \multicolumn{8}{|c|}{ Age groups } \\
\hline & \multicolumn{2}{|l|}{$55-59$} & \multicolumn{2}{|l|}{$60-64$} & \multicolumn{2}{|l|}{$65-69$} & \multicolumn{2}{|l|}{$70-74$} \\
\hline & \multicolumn{8}{|c|}{ Women } \\
\hline & \multirow{2}{*}{\multicolumn{2}{|c|}{$\begin{array}{r}-0.00136 \\
(0.3456)\end{array}$}} & \multirow{2}{*}{\multicolumn{2}{|c|}{$\begin{array}{r}-0.00105 \\
(0.3955)\end{array}$}} & \multirow{2}{*}{\multicolumn{2}{|c|}{$\begin{array}{r}-0.00100 \\
(0.4040)\end{array}$}} & \multirow{2}{*}{\multicolumn{2}{|c|}{$\begin{array}{r}-0.00115 \\
(0.2867)\end{array}$}} \\
\hline & & & & & & & & \\
\hline \multirow{2}{*}{ State UR minus national UR } & \multirow{2}{*}{\multicolumn{2}{|c|}{$\begin{array}{r}-0.00201 \\
(0.2526)\end{array}$}} & -0.00046 & & \multirow{2}{*}{\multicolumn{2}{|c|}{$\begin{array}{r}-0.00117 \\
(0.4558)\end{array}$}} & \multirow{2}{*}{\multicolumn{2}{|c|}{$\begin{array}{r}-0.00093 \\
(0.4605)\end{array}$}} \\
\hline & & & $(0.8081)$ & & & & & \\
\hline \multirow[t]{2}{*}{ Gov't bond return } & -0.00040 & * & -0.00014 & & -0.00065 & $\star \star \star *$ & \multirow{2}{*}{\multicolumn{2}{|c|}{$\begin{array}{r}-0.00018 \\
(0.2213)\end{array}$}} \\
\hline & $(0.0923)$ & & $(0.4149)$ & & $(0.0006)$ & & & \\
\hline \multirow[t]{2}{*}{ S\&P, real return } & -0.00002 & & -0.00034 & $\star *$ & -0.00030 & $\star \star *$ & \multirow{2}{*}{\multicolumn{2}{|c|}{$\begin{array}{r}-0.00002 \\
(0.7915)\end{array}$}} \\
\hline & $(0.8951)$ & & $(0.0206)$ & & $(0.0039)$ & & & \\
\hline \multirow[t]{2}{*}{ House price change } & -0.00109 & ** & -0.00047 & & 0.00000 & & \multirow{2}{*}{\multicolumn{2}{|c|}{$\begin{array}{r}-0.00010 \\
(0.7431)\end{array}$}} \\
\hline & $(0.0151)$ & & $(0.2749)$ & & $(0.9924)$ & & & \\
\hline Number of observations & $1,489,603$ & & $1,335,569$ & & $1,216,477$ & & $1,050,769$ & \\
\hline \multirow[t]{2}{*}{ Adjusted R squared } & 0.065 & & 0.069 & & 0.039 & & 0.022 & \\
\hline & \multicolumn{8}{|c|}{ Men } \\
\hline \multirow[t]{2}{*}{ Prime-age unemployment rate } & -0.00104 & & -0.00315 & \multirow[t]{2}{*}{ * } & -0.00362 & \multirow[t]{2}{*}{$* \star \star$} & -0.00280 & ** \\
\hline & $(0.3315)$ & & $(0.0652)$ & & $(0.0051)$ & & $(0.0480)$ & \\
\hline \multirow[t]{2}{*}{ State UR minus national UR } & 0.00007 & & -0.00015 & & -0.00492 & $\star \star$ & -0.00502 & ** \\
\hline & $(0.9452)$ & & $(0.9262)$ & & $(0.0133)$ & & $(0.0133)$ & \\
\hline \multirow[t]{2}{*}{ Gov't bond return } & -0.00018 & & 0.00012 & & -0.00031 & & -0.00034 & \\
\hline & $(0.4435)$ & & $(0.7326)$ & & $(0.3040)$ & & $(0.1952)$ & \\
\hline \multirow{2}{*}{ S\&P, real return } & 0.00023 & $\star \star$ & -0.00007 & & 0.00002 & & 0.00015 & \\
\hline & $(0.0259)$ & & $(0.6181)$ & & $(0.8560)$ & & $(0.2174)$ & \\
\hline \multirow[t]{2}{*}{ House price change } & -0.00044 & & -0.00022 & & -0.00018 & & -0.00045 & \\
\hline & $(0.2730)$ & & $(0.6605)$ & & $(0.6906)$ & & $(0.2511)$ & \\
\hline Number of observations & $1,364,799$ & & $1,181,459$ & & $1,012,491$ & & 800,993 & \\
\hline Adjusted R squared & 0.056 & & 0.081 & & 0.043 & & 0.027 & \\
\hline
\end{tabular}

Notes: Estimates of the linear probability model based on monthly CPS files covering the period from April 1978 through March 2010. P-values are in parenthesis. They are calculated using cluster-robust standard errors which take into account the clustering (within state) in the data. 
Figure 1. Social Security Retired-Worker Benefit Awards, 1970-2010

Thousands of awards

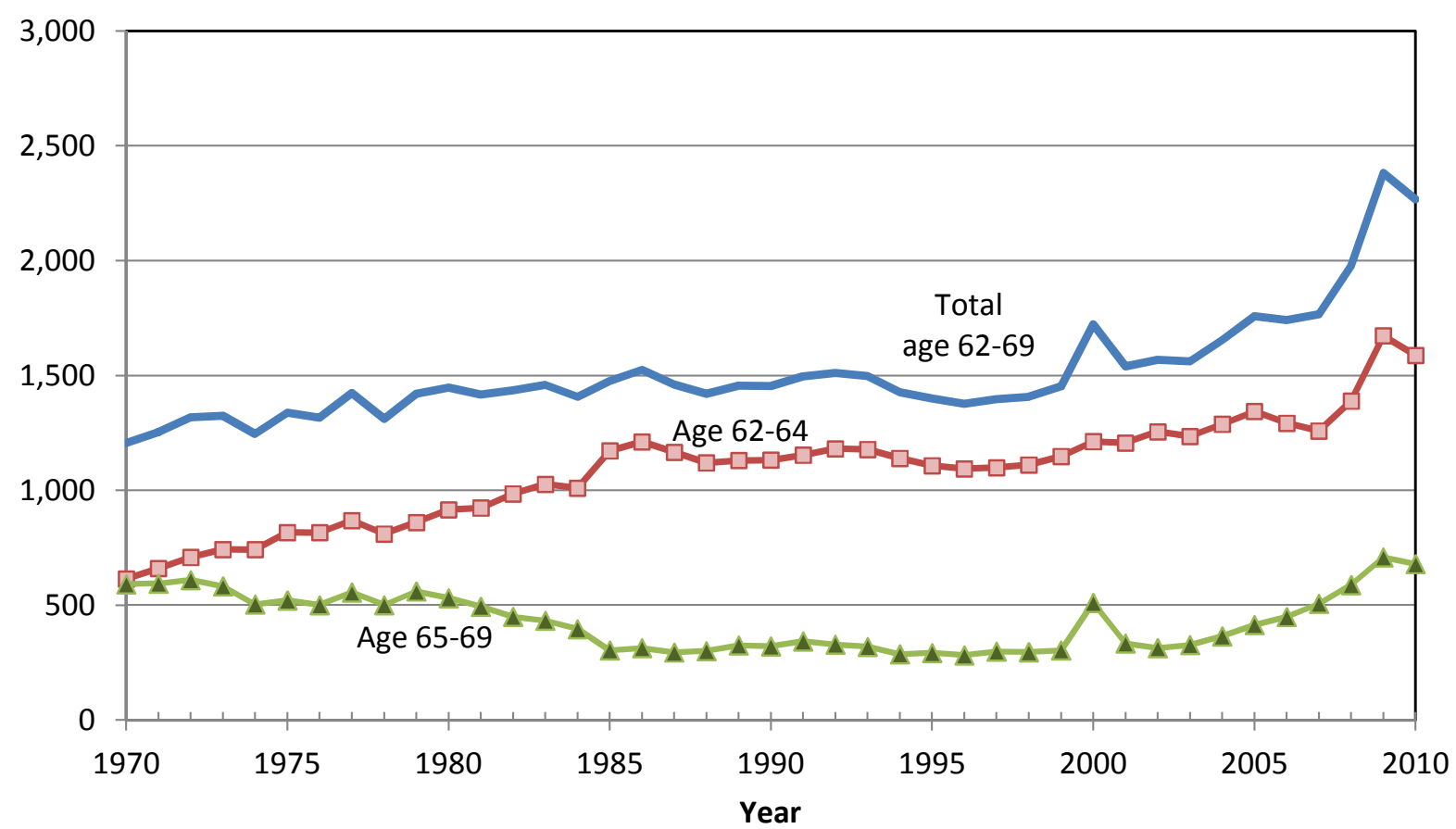

Source: Annual Statistical Supplement to the Social Security Bulletin, 2011 , table 6.B5 and prior issues.

Figure 2. Estimated Number of Persons Insured for OASI Benefits at Age 62, 1971-2010

Thousands

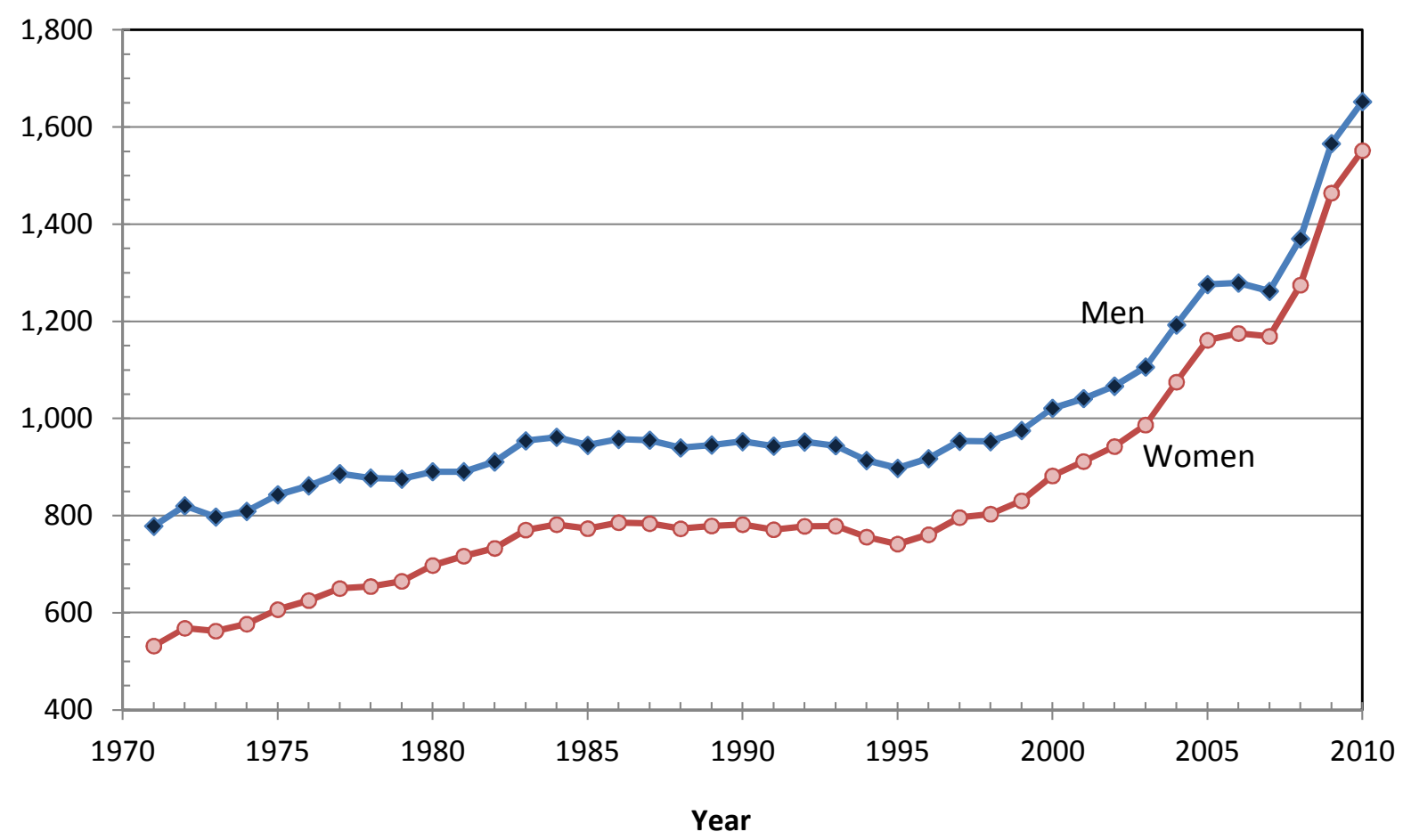

Source: Computed by the authors from data of the Social Security Adminstration and the Census Bureau. 
Figure 3. Retired-Worker Benefit Awards by Age, 1970-2010

Percent of age-specific insured population

Panel A

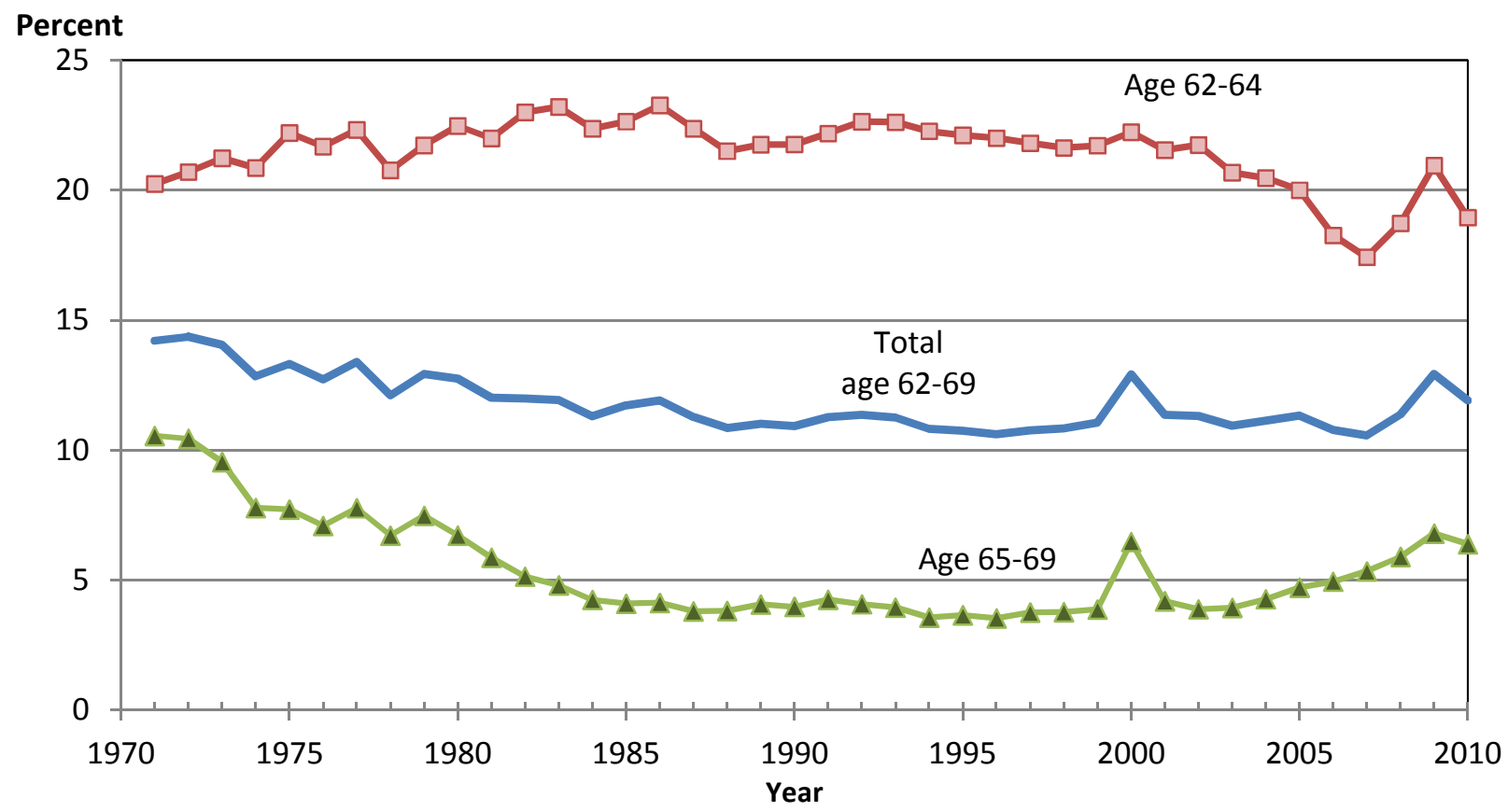

Panel B

Percent

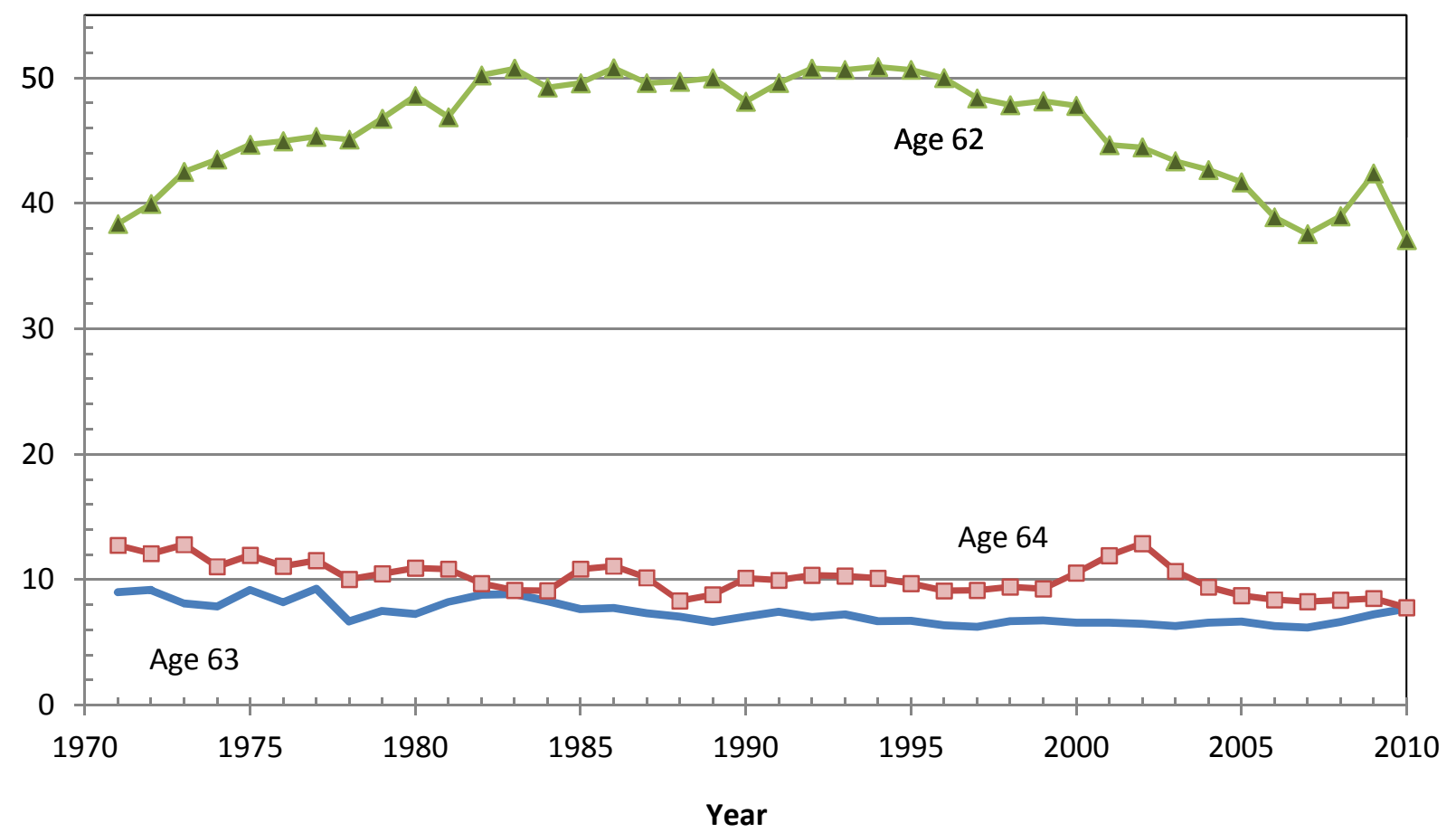

Source: Annual Statistical Supplement to the Social Security Bulletin, 2011 , table 6.B5 and prior years. The insured population by indivdiual age is constructed from data of the Social Security Administration and the Census Bureau. New awards exclude conversions from Disablilty Insurance. The percentages of the insured population are adjusted for a definitional break betweem 1984 and 1985. 
Figure 4. Alternative Measures of Labor Force Exit and Retirement. Panel A

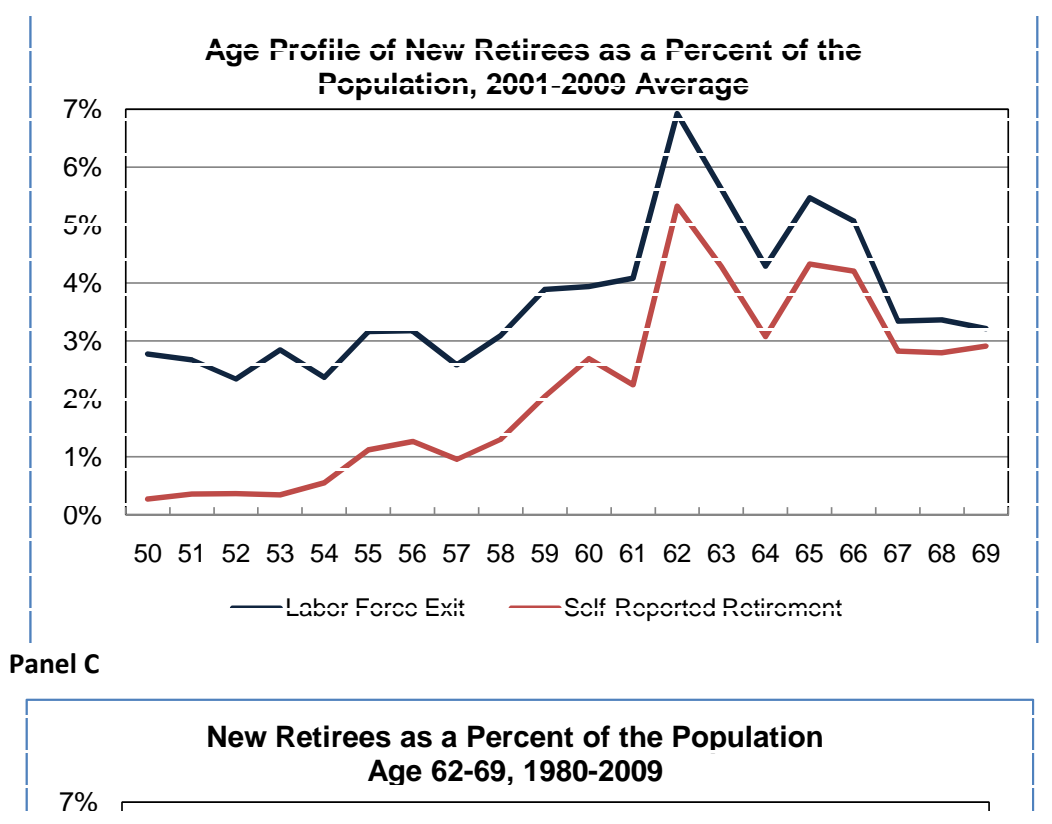

\section{Panel B}

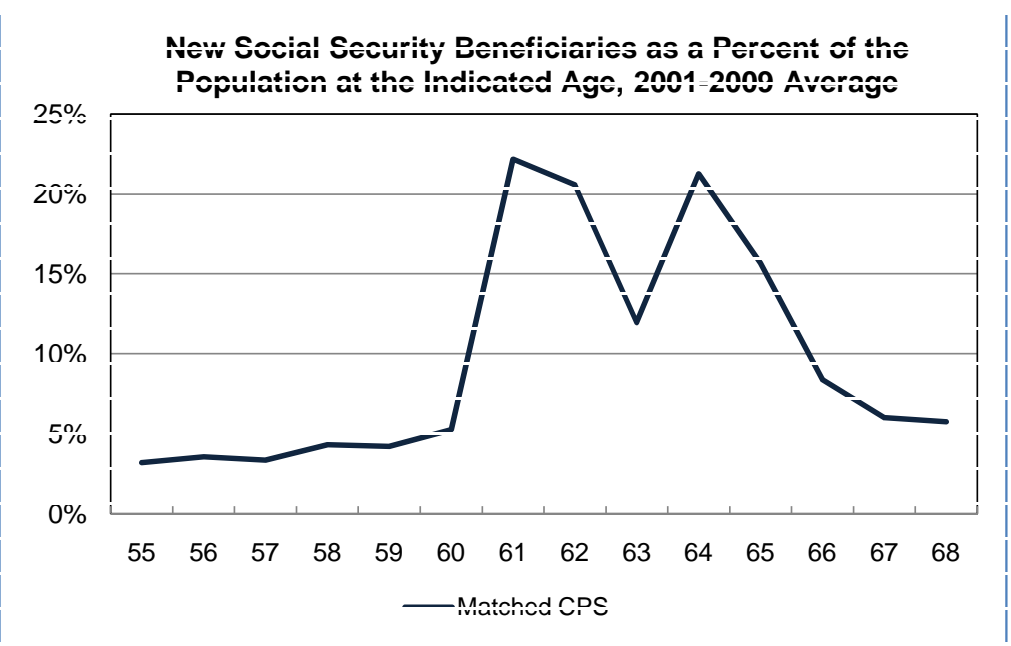

Panel D

New Social Security Beneficiaries as a Percent of the Population Age 61-68, 1980-2009 Average 
Figure 5. Female Labor Force Participation Rates at Older Ages, 1976-2010

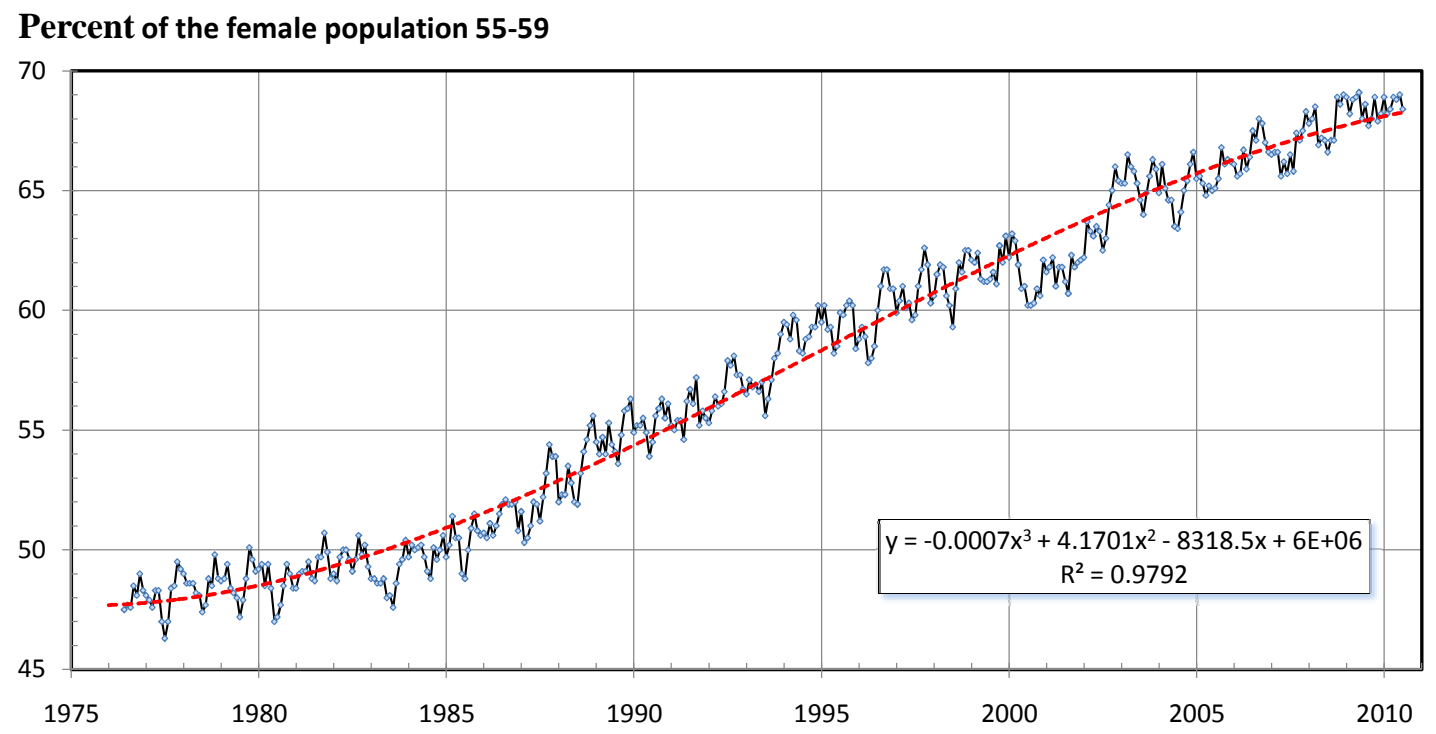

Percent of the female population 60-64

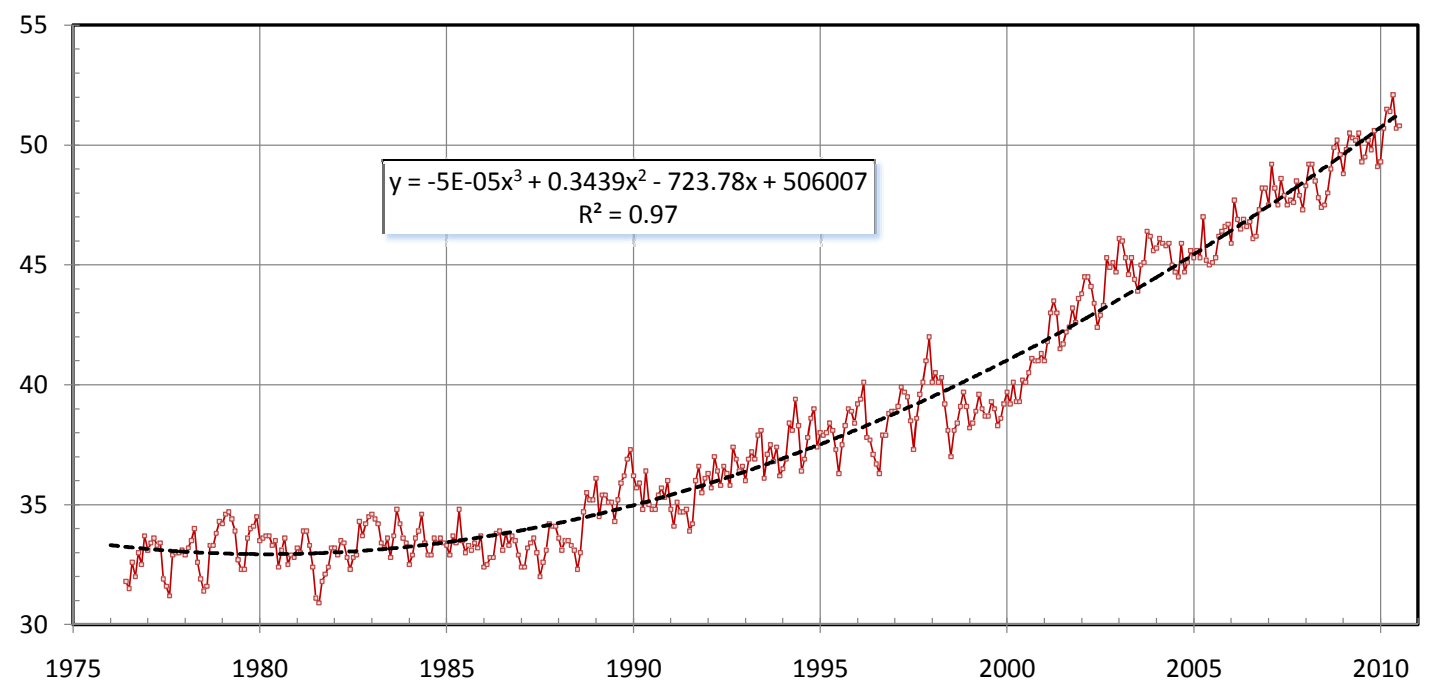

Percent of the female population 65-69

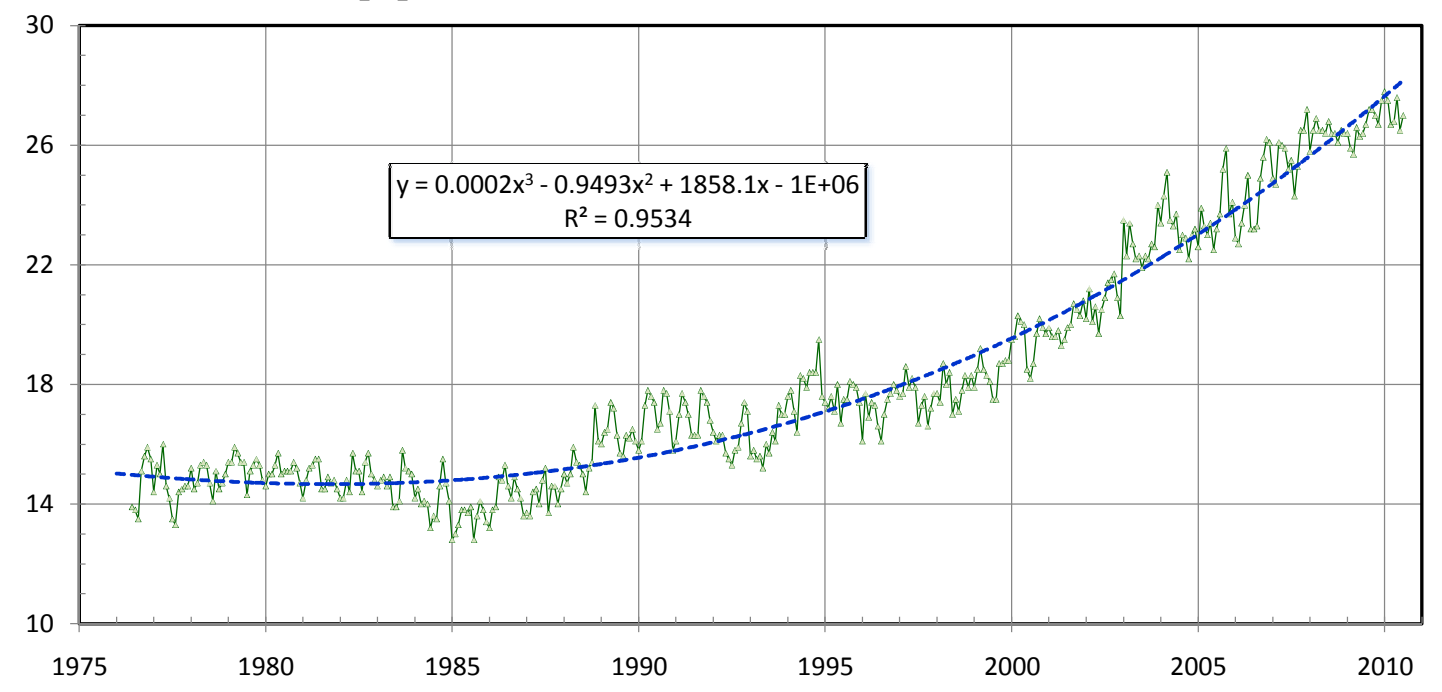

Source: Authors' tabulations of U.S. BLS data. 
Figure 6. Male Labor Force Participation Rates at Older Ages, 1976-2010
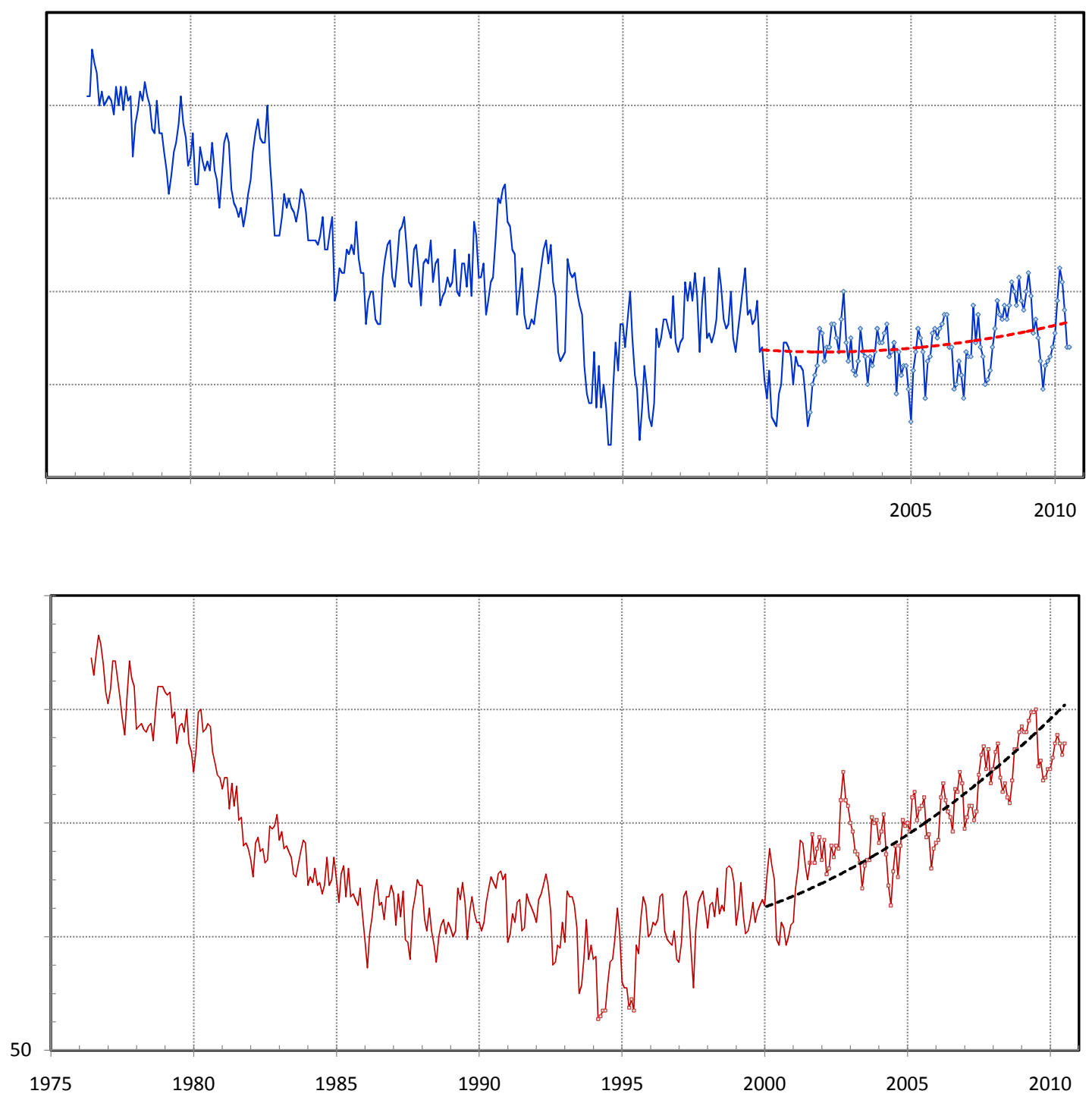

Percent of the male population 65-69

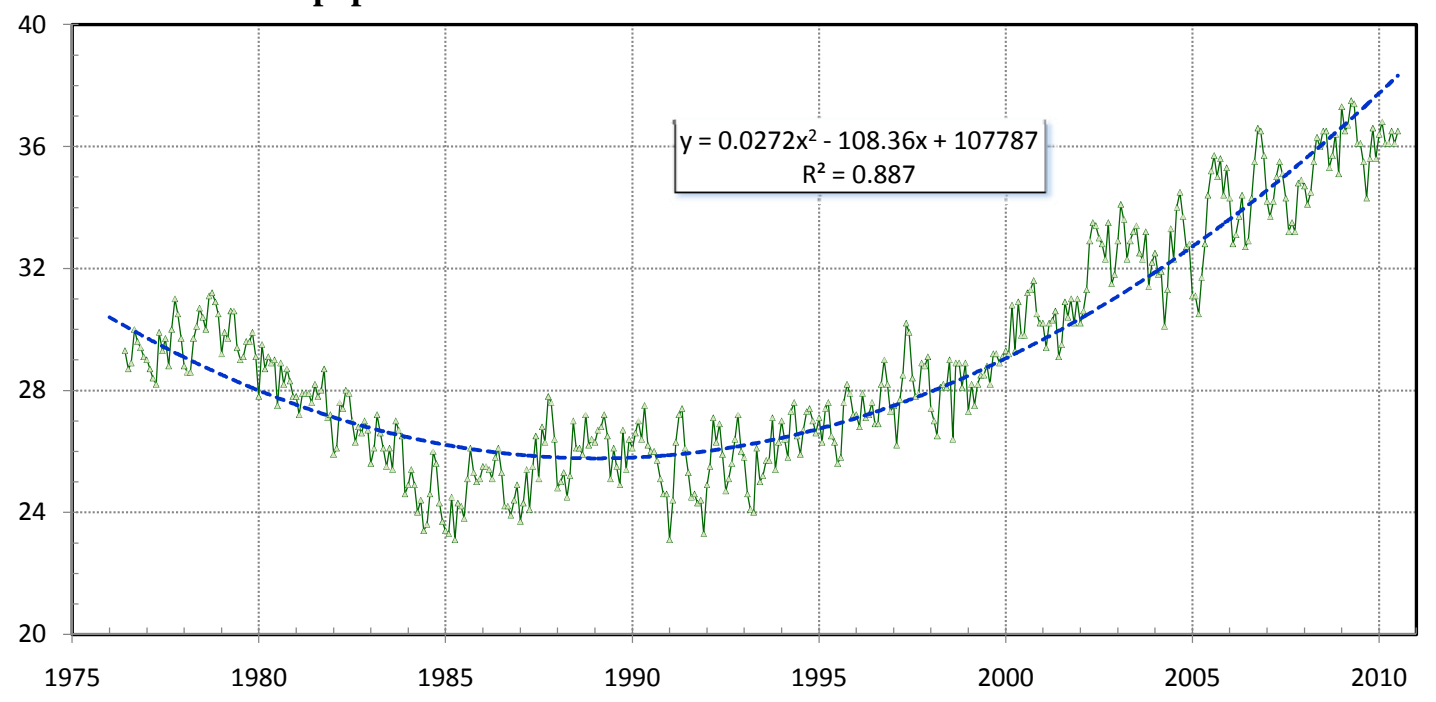

Source: Authors' tabulations of U.S. BLS data. 


\section{RECENT WORKING PAPERS FROM THE}

\section{CENTER FOR RETIREMENT RESEARCH AT BOSTON COLLEGE}

Measuring the Spillover to Disability Insurance Due to the Rise in the Full Retirement Age Norma B. Coe and Kelly Haverstick, December 2010

Is the Reduction in Older Workers' Job Tenure a Cause for Concern?

Steven A. Sass and Anthony Webb, December 2010

Accounting for Disability Insurance in the Dynamic Relationship Between Disability Onset and Earnings

Perry Singleton, November 2010

The Treatment of Married Women by the Social Security Retirement Program

Andrew G. Biggs, Gayle L. Reznik, and Nada O. Eissa, November 2010

What is the Impact of Foreclosures on Retirement Security?

Irena Dushi, Leora Friedberg, and Anthony Webb, November 2010

Children and Household Utility: Evidence from Kids Flying the Coop

Norma B. Coe and Anthony Webb, November 2010

Overview of the CRR 2009 Retirement Survey

Alicia H. Munnell, Norma B. Coe, Kelly Haverstick, and Steven A. Sass, October 2010

State Wage-Payment Laws, the Pension Protection Act of 2006, and 401(k) Saving Behavior

Gary V. Englehardt, October 2010

Asset Cycles and the Retirement Decisions of Older Workers Jan Ondrich, October 2010

Price Deflators, the Trust Fund Forecast, and Social Security Solvency Barry Bosworth, October 2010

The Impact of a DROP Program on the Age of Retirement and Employer Pension Costs Samson Alva, Norma B. Coe, and Anthony Webb, September 2010

Housing Consumption in Late Life: The Role of Income, Health Shocks, and Marital Shocks

Douglas A. Wolf and Janet M. Wilmoth, September 2010

Adjusting Social Security for Increasing Life Expectancy: Effects on Progressivity Courtney Monk, John A. Turner, and Natalia A. Zhivan, August 2010

All working papers are available on the Center for Retirement Research website (http://crr.bc.edu) and can be requested by e-mail (crr@bc.edu) or phone (617-552-1762). 